OPEN ACCESS

Edited by:

Urs Feller,

University of Bern, Switzerland

Reviewed by:

Ivan Couée,

University of Rennes 1, France

Nacer Bellaloui,

Agricultural Research Service (USDA),

USA

*Correspondence:

Rafael De Prado

qe1pramr@uco.es

Specialty section:

This article was submitted to Agroecology and Land Use Systems,

a section of the journal

Frontiers in Plant Science

Received: 10 October 2016 Accepted: 22 November 2016 Published: 06 December 2016

Citation:

Bracamonte E, Fernández-Moreno PT, Barro F and De Prado R (2016)

Glyphosate-Resistant Parthenium

hysterophorus in the Caribbean

Islands: Non Target Site Resistance and Target Site Resistance in Relation to Resistance Levels.

Front. Plant Sci. 7:1845 doi: 10.3389/fpls.2016.01845

\section{Glyphosate-Resistant Parthenium hysterophorus in the Caribbean Islands: Non Target Site Resistance and Target Site Resistance in Relation to Resistance Levels}

\author{
Enzo Bracamonte ${ }^{1}$, Pablo T. Fernández-Moreno ${ }^{2}$, Francisco Barro ${ }^{3}$ and Rafael De Prado ${ }^{2 *}$ \\ ${ }^{1}$ Faculty of Agricultural Sciences, National University of Córdoba (UNC), Córdoba, Argentina, ${ }^{2}$ Department of Agricultural \\ Chemistry and Edaphology, University of Cordoba, Cordoba, Spain, ${ }^{3}$ Department of Plant Breeding, Institute for Sustainable \\ Agriculture (IAS), Spanish National Research Council (CSIC), Cordoba, Spain
}

Glyphosate has been the most intensely herbicide used worldwide for decades, and continues to be a single tool for controlling weeds in woody crops. However, the adoption of this herbicide in a wide range of culture systems has led to the emergence of resistant weeds. Glyphosate has been widely used primarily on citrus in the Caribbean area, but a study of resistance in the Caribbean islands of Cuba and the Dominican Republic has never been carried out. Unfortunately, Parthenium hysterophorus has developed glyphosate-resistance in both islands, independently. The resistance level and mechanisms of different $P$. hysterophorus accessions (three collected in Cuba (Cu-R) and four collected in the Dominican Republic (Do-R) have been studied under greenhouse and laboratory conditions. In in vivo assays (glyphosate dose causing 50\% reduction in above-ground vegetative biomass and survival), the resistance factor levels showed susceptible accessions (Cu-S $\geq$ Do-S), low-resistance accessions (Cu-R3 < Do-R4), medium-resistance accessions (Do-R3 < Cu-R2 < Do-R2) and high-resistance accessions (Do-R1 < Cu-R1). In addition, the resistance factor levels were similar to those found in the shikimic acid accumulation at $1000 \mu \mathrm{M}$ of glyphosate (Cu-R1 $\geq$ Do-R1 > Do-R2 > Cu-R2 > Do-R3 > Do-R4 > Cu-R3 > > Cu-S $\geq$ Do-S). Glyphosate was degraded to aminomethylphosphonic acid, glyoxylate and sarcosine by $>88 \%$ in resistant accessions except in Cu-R3 and Do-R4 resistant accessions (51.12 and 44.21, respectively), whereas a little glyphosate $(<9.32 \%)$ was degraded in both susceptible accessions at $96 \mathrm{~h}$ after treatment. There were significant differences between $P$. hysterophorus accessions in the 5-enolpyruvylshikimate-3-phosphate synthase (EPSPS) activity enzyme with and without different glyphosate rates. The $R$ accessions showed values of between 0.026 and $0.21 \mu \mathrm{mol} \mu \mathrm{g}^{-1} \mathrm{TSP}$ protein $\mathrm{min}^{-1}$ basal EPSPS activity values with respect to the $S(0.024$ and 0.025$)$ accessions. The same trend was found in the EPSPS enzyme activity treated with glyphosate, where a higher enzyme activity inhibition (glyphosate $\mu \mathrm{M}$ ) corresponded to greater resistance levels in P. hysterophorus accessions. One amino acid substitution was found at position 
106 in EPSPS, consisting of a proline to serine change in Cu-R1, Do-R1 Do-R2. The above-mentioned results indicate that high resistance values are determined by the number of defense mechanisms (target-site and non-target-site resistance) possessed by the different $P$. hysterophorus accessions, concurrently.

Keywords: $P$. hysterophorus, target-site and non-target-site mechanisms, resistance levels, glyphosate

\section{INTRODUCTION}

Herbicide resistance is an evolutionary phenomenon that allows resistant weed biotypes to be exposed to the normal dose of a herbicide undergoing any suffering growth alterations (Fernández et al., 2016). This biological phenomenon is favored by intensive herbicide applications with the same active ingredient or with the same mode of action (Neve et al., 2014; Evans et al., 2016). Glyphosate weed resistance is one of the world's most interesting cases, 35 glyphosate-resistant species have been detected and characterized (mainly using test dose response curves and shikimic acid accumulation) up to date (Heap, 2016).

Glyphosate ((N-phosphonomethyl)-glycine) is a postemergent herbicide that is non-selective, highly systemic and widely used for weed control around the world (Franz et al., 1997; Székács and Darvas, 2012). It is well metabolized in plants and slow-acting with visible phytotoxic symptoms in sensitive plants at 10-20 days after application (Amrhein et al., 1980; Shingh and Shaner, 1998; Monquero et al., 2004). It inhibits the shikimate pathway by inhibiting 5-enolpyruvylshikimate-3-phosphate synthase (EPSPS), which catalyzes the synthesis reactions of aromatic amino acids involved in the formation of essential proteins in plants (Sammons and Gaines, 2014).

Glyphosate resistance selection is due to two different mechanisms known as non-target site resistance (NTSR) and target site resistance (TSR) (Shaner et al., 2012; Sammons and Gaines, 2014). NTSR involves a reduced rate of herbicide in the meristem tissues due to limited absorption/translocation, and/or sequestration of the herbicide into compartments such as vacuoles (Michitte et al., 2007; Ge et al., 2012; Vila-Aiub et al., 2012). Metabolic pathways capable of degrading the herbicide to non-toxic compounds in plants also belong to these group mechanisms (De Prado and Franco, 2004; Cruz-Hipólito et al., 2009, 2011; Busi et al., 2011; de Carvalho et al., 2012; GonzálezTorralva et al., 2012; Alcántara-de la Cruz et al., 2016a). TSR has been produced by one or more mutations in the DNA sequence (González-Torralva et al., 2014; Sammons and Gaines, 2014; Fernández et al., 2015; Yu et al., 2015), or by the overexpression of the EPSPS protein by gene amplification (Gaines et al., 2010; Salas et al., 2012, 2015).

When growers reported noticing any deficiency in their weed control, they usually increased the glyphosate doses, which increased the pressure selection as well as triggering the acquisition of a second resistance mechanism (Jasieniuk et al., 1996; González-Torralva et al., 2012). Then, the level of weed resistance to glyphosate increased (Bostamam et al., 2012).

Ragweed parthenium (Parthenium hysterophorus L.) is a troublesome annual weed of the Asteraceae family that is native to the Gulf of Mexico and other Latin American countries (Rosario et al., 2013). Its prolific seed production (130,000-200,000 seeds $\mathrm{m}^{-2}$ ), as well as the seeds's ability to persist in the soil and germinate over a wide range of temperatures, have contributed to the widespread distribution of ragweed parthenium in perennial and annual crops (orchards, citrus, soybean, corn) as well as in surrounding areas (Joshi, 1991; Pandey et al., 2003; Navie et al., 2004; Adkins and Shabbir, 2013). In addition, the subtropical environment of the Caribbean Islands (Cuba and Dominican Republic) allows year-round germination, growth, and reproduction of ragweed parthenium, which also contributes to its widespread distribution in the region. Glyphosate has been used repeatedly in perennial crop areas and fallow fields in the Caribbean Islands for many years to manage ragweed parthenium and other troublesome weeds. However, growers have recently observed reduced ragweed parthenium control with single or multiple glyphosate applications. Previous reports have documented glyphosate-resistant ragweed parthenium in Colombia (Rosario et al., 2013), Florida (southeast US) (Fernandez, 2013) and Dominican Republic (Jimenez et al., 2014), but in these three cases the causes of resistance to glyphosate have been inconclusive.

The main objective of this work is a survey of $P$. hysterophorus in Cuba and the Dominican Republic that had never been done before. The specific objectives were to determine (1) the level of glyphosate resistance of different accessions; (2) the possible NTSR and TSR mechanisms involved; and (3) to find out if the resistance genes may also increase the multiplicative or additive resistance levels in P. hysterophorus.

\section{MATERIALS AND METHODS}

\section{Plant Material}

In 2013, mature P. hysterophorus seeds were collected from plants not controlled with glyphosate at doses normally used $\left(2 \mathrm{~L} \mathrm{ha}^{-1}\right.$; $720 \mathrm{~g} \mathrm{ae} \mathrm{ha}^{-1}$ ) in areas with perennial crops in two Caribbean Islands. Seeds from Cu-S and Do-S accessions never exposed to glyphosate were collected from adjacent areas and used as a reference control (Table 1). Seeds collected from 25 mature plants were stored under laboratory conditions $\left(25^{\circ} \mathrm{C}\right)$ for 2 weeks and then placed in paper bags at $4^{\circ} \mathrm{C}$. Approximately 300 seeds of these accessions were sown directly into trays (40 $\times 60 \times 15 \mathrm{~cm})$, containing a mixture of sand and peat $(2: 1$, $\mathrm{v} / \mathrm{v}$ ) and placed in a greenhouse at $28 / 20^{\circ} \mathrm{C}$ day/night under a $16 \mathrm{~h}$ photoperiod with $850 \mu \mathrm{mol} \mathrm{m}{ }^{-2} \mathrm{~s}^{-1}$ photon flux density, and $80 \%$ relative humidity. At the four leaf stage plants of all accessions were treated with glyphosate at $720 \mathrm{~g} \mathrm{ae} \mathrm{ha}^{-1}$ using a laboratory spray chamber equipped with a flat fan nozzle (Tee)et 8002 EVS) with a total output volume of $200 \mathrm{~L} \mathrm{ha}^{-1}$ water at 
TABLE 1 | History of different $P$. hysterophorus accessions used in this study.

\begin{tabular}{|c|c|c|c|}
\hline Accessions $^{a}$ & Location & Crop & $\begin{array}{l}\text { Glyphosate }^{\text {b }} \text { (time of } \\
\text { applications per year), } \\
\text { number of application years }\end{array}$ \\
\hline Cu-R1 & Ceiba & Orchards ${ }^{\mathrm{C}}$ & 720 (2 or 3 times), >10 \\
\hline Cu-R2 & Ceiba & Citrus $^{\mathrm{C}}$ & 720 (1 time), $>10$ \\
\hline Cu-R3 & Arimao & Citrus & 720 (2 times), unknown \\
\hline Cu-S & Arimao & Road trails & No herbicide treatment \\
\hline Do-R1 & Villa Altagracia & Citrus $^{c}$ & 900 (2 times), >15 \\
\hline Do-R2 & San Cristobal & Citrus & 900 (2 times), > 15 \\
\hline Do-R3 & Monseñor Nouel & Citrus & 720 (2 times), > 10 \\
\hline Do-R4 & Maria T. Sánchez & Orchards & 720 (1 time), $>10$ \\
\hline Do-S & Maria T. Sanchez & Road trails & No herbicide treatment \\
\hline
\end{tabular}

${ }^{a} C u, P$. hysterophorus harvested in Cuba; Do, P. hysterophorus harvested in Dominican Republic; ${ }^{b}$ glyphosate $g$ ae $h \mathrm{a}^{-1}{ }^{\text {; }}$ cthe last application was performed manually for every plant.

a pressure of $200 \mathrm{kPa}$. Four weeks after glyphosate treatment plant survival of the resistant accessions was estimated, and seed produced from surviving plants was collected and stored in paper bags for all subsequent trials. In the case of susceptible accessions (Cu-S and Do-S), no plant survival was observed 4 weeks after glyphosate treatment.

\section{Dose-Response Assay}

Seeds of putative resistant (Cu-R1, Cu-R2, Cu-R3, Do-R1, Do$\mathrm{R} 2$, Do-R3, and Do-R4) and susceptible (Cu-S and Do-S) of the $P$. hysterophorus accessions were germinated in trays (12 $\times 12 \times 6 \mathrm{~cm})$ containing the same substrate as described before and placed in a growth chamber of similar environmental conditions controlled as before. One week after germination, individual seedlings were transplanted into pots $(6 \times 6 \times$ $8 \mathrm{~cm}$ ) and grown under fluctuating $30 / 20^{\circ} \mathrm{C}$ day/night with a $14 \mathrm{~h}$ photoperiod and $850 \mu \mathrm{mol} \mathrm{m} \mathrm{m}^{-2} \mathrm{~s}^{-1}$ photon flux density, and $80 \%$ relative humidity. As glyphosate (EPSPS inhibitor) is used in early post-emergence, at the four leaf stage, resistant and susceptible $P$. hysterophorus seedlings were treated with increasing glyphosate doses: 0, 31.25, 62.5, 125, 250, 500, 1000, 2000, 4000, and $8000 \mathrm{~g}_{\text {ae }} \mathrm{ha}^{-1}$ (Roundup Energy 45\% w/v, SL, Monsanto Spain). The experiment were conducted with 10 replications (one plant pot $^{-1}$ ) of each accession per herbicide dose, and the experiments were repeated twice. Thirty days after herbicide treatment, herbicide effects on plant survival (LD) and above-ground vegetative biomass (GR) were assessed.

\section{Leaf Segment Shikimate Accumulation Assay}

Leaf segments (50 mm diameter) were harvested from the youngest fully expanded leaf from a batch of 15 plants per $P$. hysterophorus accessions at the 4-6 leaf stage (Hanson et al., 2009). Approximately $50 \mathrm{mg}$ of fresh tissue was transferred to $2 \mathrm{~mL}$ Eppendorf tubes containing $1 \mathrm{~mL}$ of $1 \mathrm{mM} \mathrm{NH}_{4} \mathrm{H}_{2} \mathrm{PO}_{4}$ ( $\mathrm{pH}$ 4.4). Glyphosate was added to the tubes at the following concentrations: $0,0.1,0.5,1,5,10,50,100,200,400,500$,
600, and $1000 \mu \mathrm{M}$. The Eppendorf tubes were incubated in a growth chamber during $24 \mathrm{~h}$ under the previously described conditions. After $24 \mathrm{~h}$, the tubes were stored at $-20^{\circ} \mathrm{C}$ until analysis. Eppendorf tubes were removed from the freezer and thawed at $60^{\circ} \mathrm{C}$ for $30 \mathrm{~min}$. Two hundred and fifty micro liters of $1.25 \mathrm{~N} \mathrm{HCL}$ was added to each tube, and placed at $60^{\circ} \mathrm{C}$ for $15 \mathrm{~min}$. A $125 \mu \mathrm{L}$ aliquot from each tube was pipetted into a new $2 \mathrm{~mL}$ Eppendorf tube, and $500 \mu \mathrm{L}$ of periodic acid and sodium metaperiodate $(0.25 \%$ [wt/v] each) was added. They were incubated at room temperature for $90 \mathrm{~min}$, after which 500 $\mu \mathrm{L}$ of $0.6 \mathrm{~N}$ sodium hydroxide and $0.22 \mathrm{M}$ sodium sulfite was added. The contents of all tubes were transferred to glass vials. Samples were measured in a spectrophotometer at $380 \mathrm{~nm}$ within $30 \mathrm{~min}$. For each glyphosate concentration and accession, three replications were stablished and repeated twice.

\section{${ }^{14} \mathrm{C}$ Glyphosate Absorption and Translocation}

Absorption and translocation study was carried out following the methodology proposed by Cruz-Hipólito et al. (2011) The ${ }^{14} \mathrm{C}$ glyphosate was mixed with commercially formulated glyphosate to prepare a solution with a specific activity of $0.834{\mathrm{kBq} \mu \mathrm{L}^{-1}}^{-1}$ and a glyphosate concentration of $1.8 \mathrm{~g}$ ae $\mathrm{L}^{-1}\left(360 \mathrm{~g}\right.$ ae ha ${ }^{-1}$ in $200 \mathrm{~L})$. P. hysterophorus plants at 4-leaf stage were treated with the radiolabeled herbicide by applying one droplet of $1 \mu \mathrm{L}$ of glyphosate solution $\left(0.834 \mathrm{kBq} \mu \mathrm{L}^{-1}\right)$ on the adaxial surface of the second leaf in each plant using a micropipette (LabMate). The ${ }^{14} \mathrm{C}$-glyphosate unabsorbed in the treated leaf was removed with $3 \mathrm{~mL}$ of water: acetone solution $(1: 1, \mathrm{v} / \mathrm{v}) 96 \mathrm{~h}$ after droplet application. Preliminary assays with two accessions (Cu-R1 and $\mathrm{Cu}-\mathrm{S}$ ) studied had revealed that the glyphosate absorption leveled-off at $96 \mathrm{~h}$ after the droplet applications. The rinsate was mixed with $2 \mathrm{~mL}$ of scintillation liquid and analyzed by liquid scintillation spectrometry (LSS) (Scintillation Counter, Beckman LS 6500, Fullerton CA). The plants were separated into the treated leaf, rest of the shoot and root after being placed in cellulose cones. The plant tissue was dried at $60^{\circ} \mathrm{C}$ over $96 \mathrm{~h}$ and combusted in a biological sample oxidizer (Packard Tri Carb 307, Perkin-Elmer, Waltham, MA). The ${ }^{14} \mathrm{CO}_{2}$ evolved was trapped and counted in $18 \mathrm{~mL}$ of a mixture of Carbo-Sarb $\mathrm{E}$ and Permafluor (9:9, v/v) (Perkin-Elmer). Thus, over 95\% of the total radioactivity applied was recovered. There were five replications and the experiment was arranged in a completely randomized design, and repeated twice. The proportion of absorbed herbicide was expressed as:

$$
\begin{aligned}
{[\% \text { absorbed }=} & (\mathrm{kBq} \text { in combusted tissue } /(\mathrm{kBq} \text { in combusted } \\
& \text { tissue }+\mathrm{kBq} \text { in leaf washes })) \times 100] .
\end{aligned}
$$

\section{Glyphosate Metabolism}

$P$. hysterophorus plants were treated with a glyphosate rate of $360 \mathrm{~g}$ ae $\mathrm{ha}^{-1}$ at $4-6$ leaf stage. At $96 \mathrm{~h}$ after treatment (HAT), glyphosate and its metabolites, i.e., AMPA (aminomethylphosphonic acid), glyoxylate and sarcosine, were determined by reversed-polarity capillary electrophoresis following the methodology described by Rojano-Delgado 
et al. (2010). The calibration equations were established using non-treated plants and known concentrations of glyphosate and its metabolites, which were determined from their enclosed areas under the peaks in the electropherogram. The average value for the amount of glyoxylate naturally produced by the plant was subtracted from the average of the produced or reduced amount after treatment of each accession (Rojano-Delgado et al., 2010). The experiment was arranged in a completely randomized design with four replications per accession and repeated three times.

\section{EPSPS Enzyme Activity Assays}

The enzyme extraction was conducted according to the protocol described by Dayan et al. (2015). Five gram of the leaf tissue of all P. hysterophorus accessions (Table 1) were ground to fine powder in a chilled mortar. Immediately after that, the powdered tissue was transferred to tubes containing $100 \mathrm{~mL}$ of cold extraction buffer (100 mM MOPS, $5 \mathrm{mM}$ EDTA, 10\% glycerol, $50 \mathrm{mMKCl}$ and $0.5 \mathrm{mM}$ benzamidine) containing $70 \mu \mathrm{L}$ of $\beta$ mercaptoethanol and $1 \%$ in polyvinylpolypyrrolidone (PVPP). Samples were stirred and subsequently centrifuged for $40 \mathrm{~min}$ $(18,000 \mathrm{~g})$ at $4^{\circ} \mathrm{C}$. The supernatant was decanted into a beaker using a cheesecloth. $\left(\mathrm{NH}_{4}\right)_{2} \mathrm{SO}_{4}$ was added to the solution to obtain $45 \%(\mathrm{w} / \mathrm{v})$ concentration, with stirring during $30 \mathrm{~min}$. After that, the mix was centrifuged at $20,000 \mathrm{~g}$ for $30 \mathrm{~min}$ at $4^{\circ} \mathrm{C}$. The previous step was repeated to precipitate the protein in the extracts but in that case with a $\left(\mathrm{NH}_{4}\right)_{2} \mathrm{SO}_{4}$ concentration of $80 \%$ $(\mathrm{w} / \mathrm{v})$ stirring for $30 \mathrm{~min}$. Finally, they were centrifuged at 20,000 $\times \mathrm{g}$ for $30 \mathrm{~min}$ at $4^{\circ} \mathrm{C}$.

All the pellets were dissolved in $3 \mathrm{~mL}$ of extraction buffer and dialyzed in $2 \mathrm{~L}$ of dialysis buffer $(30 \mathrm{~mm}, 1000-\mathrm{MWC}$ dialysis tubing at $4^{\circ} \mathrm{C}$ on a stir plate) over $12 \mathrm{~h}$. The protein concentrations were determined by Bradford assay (Bradford, 1976).

The assay for the determination of EPSPS activity followed the methodology described by Dayan et al. (2015) using the EnzCheck phosphate assay Kit (Invitrogen, Carlsbad, CA) to determine the inorganic phosphate release. The EPSPS activity from the nine accessions was determined in the presence and absence of glyphosate. The glyphosate concentrations used were: $0,0.1,1,10,100$, and $1000 \mu \mathrm{M}$ to determine the enzyme activity inhibition $\left(\mathrm{I}_{50}\right)$. The assay buffer was composed of $1 \mathrm{mM} \mathrm{MgCl}_{2}$, $10 \%$ glycerol, and $100 \mathrm{mM}$ MOPS, $2 \mathrm{mM}$ sodiummolybdate and $200 \mathrm{mM} \mathrm{NaF}$. The experiments were conducted with three replications of each accession per glyphosate concentration and repeated three times. EPSPS enzyme activity was expressed as percentage of enzyme activity in presence of glyphosate respect to the control (without glyphosate).

\section{EPSP Synthase Gene Sequencing}

For RNA extraction 100-200 mg of young leaves were taken from plants of each $P$. hysterophorus accession, and stored at $-80^{\circ} \mathrm{C}$ for the extraction of RNA. Their tissue was ground in liquid nitrogen in a STAR-BEATER 412-0167 mill (VWR International Eurolab S.L., Barcelona, Spain). Total RNA was isolated from leaves as described by Pistón (2013), and the amount and quality were determined in a NanoDrop ND-1000 spectrophotometer (Thermo Scientific, Walthman, MA, USA).
The synthesis to cDNA was from total RNA being adjusted to the same concentration in all the samples $\left(50 \mathrm{ng} \mu \mathrm{L}^{-1}\right)$. An iScript ${ }^{\mathrm{TM}}$ cDNA Synthesis Kit (Bio-Rad Laboratories, Inc. CA, USA) at $40 \mu \mathrm{L}$ reaction volume was used following the manufacturer's instructions.

The PCR reactions were carried out with cDNA samples from each of the accession using the primers Bidens-F10 (5'- GGTTGTGGYGGTVTRTTTCC-3') and Bidens-R11 (5'GTCCCAASTATCACTRTGTTC- $3^{\prime}$ ) based on EPSPS gene sequences described previously (Alcántara-de la Cruz et al., 2016b). PCR conditions were also as described (Alcántarade la Cruz et al., 2016b). The PCR on cDNA amplified fragments of 462 bp in length, comprising the region of Thr-102 and Pro-106, which corresponds to the sequence of the EPSPS gene of Arabidopsis Klee et al. (1987), in which point mutations conferring resistance to glyphosate have been associated (Sammons and Gaines, 2014; Yu et al., 2015).

The PCR fragments were cloned in the pGEM $^{\circledR}$-T Easy Vector System (Promega Biotech Ibérica, SL, Madrid, Spain) and transformed into competent cells of $E$. coli $\mathrm{DH} 5 \alpha$ (Promega). Transformation was confirmed through PCR using the M13F and M13R primers as described (Alcántara-de la Cruz et al., 2016b). The colonies containing the length of the fragment were sequenced by the STABVIDA sequencing service (Caparica, Portugal). Five biological samples were used per accession providing 15 clones in all for each one. The quality and assembly of cDNA sequences and consensuses were determined employing the programs of SeqMan Pro ${ }^{\text {TM }}$ versión 11(DNASTAR; Wisconsin, USA) and Geneious ${ }^{\circledR}$ versión 8.1.8 (Biomatters Ltd, Auckland, New Zealand). The multiple sequences were aligned by means of the Muscle algorithm incorporated into SeqMan Pro versión 11.

\section{Data Analysis}

Dose-Response and EPSPS enzyme activity data were subjected to non-linear regression analysis (Seefeldt et al., 1995; Burgos et al., 2013) using a three-parameter log-logistic equation (Equation 1) to determine the glyphosate dose causing 50\% reduction in above-ground vegetative biomass $\left(\mathrm{GR}_{50}\right), 50 \%$ mortality $\left(\mathrm{LD}_{50}\right)$, and inhibition of EPSPS activity by $50 \%\left(\mathrm{I}_{50}\right)$.

$$
Y=\left\{\left[(d) /\left(1+(x / g)^{b}\right)\right]\right\}
$$

Where $Y$ is the EPSPS activity, survival or above-ground biomass at herbicide $x$ dose, $d$ is the coefficient corresponding to the upper asymptote, $b$ is the slope of the curve, and $g$ is the herbicide rate at the point of inflection halfway (i.e., $\mathrm{LD}_{50}, \mathrm{GR}_{50}, \mathrm{I}_{50}$ ).

Regression analyses were conducted using the $d r c$ package (Ritz et al., 2015) for the statistical environment R ( R 3.2.4; R Core Team, 2015). Resistance indices were computed as R-to-S $\mathrm{GR}_{50} \mathrm{LD}_{50}$, or $\mathrm{I}_{50}$ ratios. To test for a common $\mathrm{GR}_{50}, \mathrm{LD}_{50}$, or $\mathrm{I}_{50}$ for $\mathrm{R}$ and $\mathrm{S}$ accessions, i.e., Resistance Index equals to 1 , a lack-offit test was used to compare the model consisting of curves with accessions-specific $g$ values with a reduced model with common g (Ritz et al., 2015).

Analysis of variance (ANOVA) was conducted using Statistix 9.0 (Analytical Software, USA) to test for differences between 


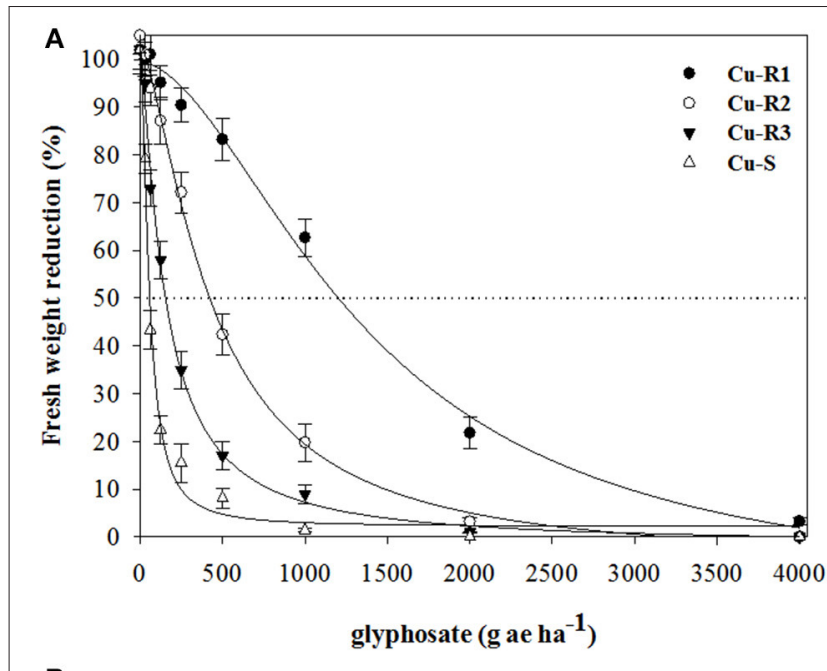

B

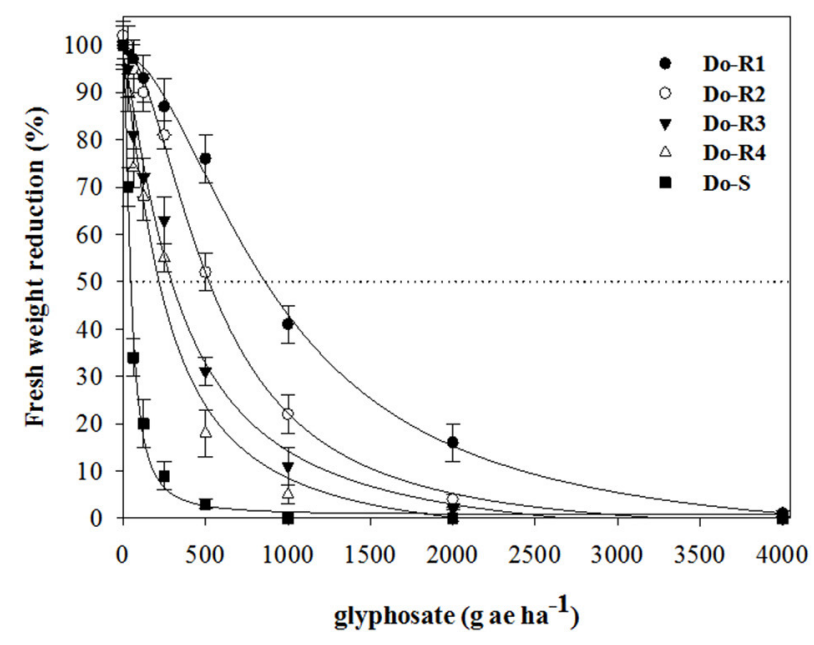

FIGURE 1 | Shoot biomass in glyphosate-resistant and susceptible P. hystherophorus accessions from Cuba (A) and Dominican Republic (B) 30 days after treatment. Symbols denoted mean $(n=10) \pm$ standard errors of the mean.

$\mathrm{R}$ and $\mathrm{S}$ accessions in shikimate accumulation at $1000 \mu \mathrm{M}$ glyphosate in the leaf segment; and proportion of the different glyphosate metabolites; proportion of applied ${ }^{14} \mathrm{C}$-glyphosate taken up by leaves, and proportions of absorbed ${ }^{14} \mathrm{C}$-glyphosate remaining in the treated leaf, translocated to roots and to the rest of the plant at $96 \mathrm{HAT}$; and basal enzyme activity. Percentage data were previously transformed (arcsine of the square root) to meet model assumptions. Model assumptions of normal distribution of errors and homogeneous variance were graphically inspected. When needed, differences between means were separated using the Tukey HSD test.

\section{RESULTS}

\section{Physiological Studies}

Dose-response assays showed the existence of the first case of glyphosate-resistant weeds in the Caribbean (Cuba and

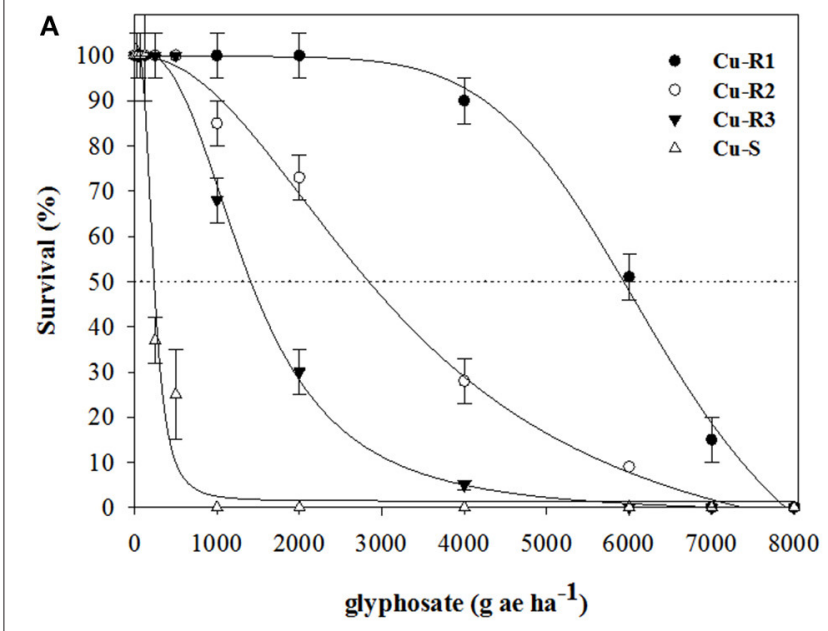

B

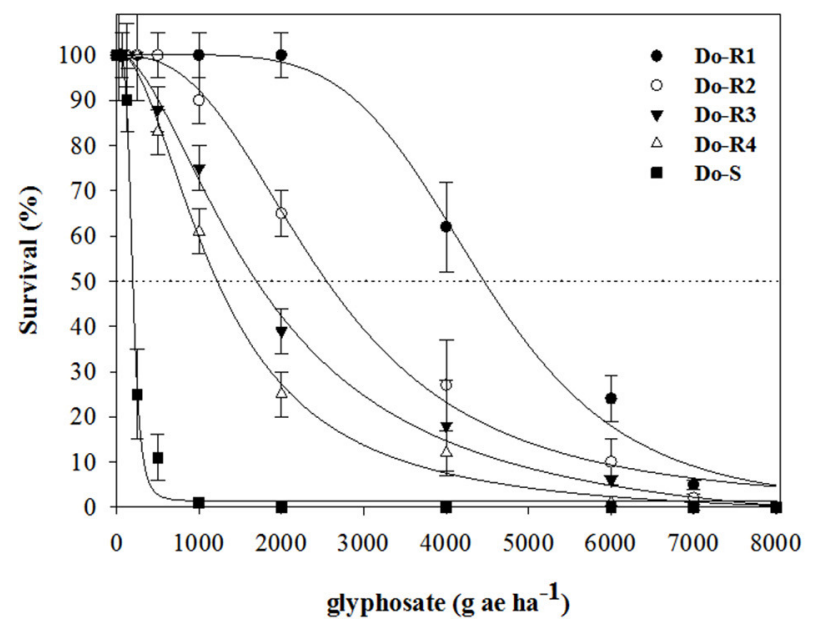

FIGURE 2 | Survival plants in glyphosate-resistant and susceptible P. hystherophorus accessions from Cuba (A) and Dominican Republic (B) 30 days after treatment. Symbols denoted mean $(n=10) \pm$ standard errors of the mean.

Dominican Republic). The two susceptible weeds (Cu-S and Do-S) had similar susceptibility levels (Figures 1, 2; Table 2). The $P$. hyterophorus accessions from Cuba island had resistance index (RI) values (based on the $\mathrm{GR}_{50}$ and $\mathrm{LD}_{50}$ values) that ranged from 2.7 to 24.6 , and 6.1 to 27.5 fold resistance, respectively, while on Dominican Republic island values were between 5.4 to 20, and 6.3 to 22.7 fold resistance, respectively (Table 2 ).

The fact that plants treated with glyphosate increase shikimic acid accumulation in leaf disks due to the inhibition of EPSPS activity led us to carry out the experiment depicted in Figures 3A,B. Considering the values obtained in vivo $\left(\mathrm{GR}_{50}\right.$ and $\mathrm{LD}_{50}$ ) and the shikimic acid accumulation in leaf disks at $1000 \mu \mathrm{M}$ of glyphosate, the resistance order of the $P$. hystherophorus accessions was $\mathrm{Cu}-\mathrm{R} 1 \geq \mathrm{Do}-\mathrm{R} 1>$ Do- $2>\mathrm{Cu}-$ $\mathrm{R} 2>$ Do-R3 $>$ Do-R4 $>$ Cu-R3 $>>$ Cu-S $\geq$ Do-S. There were significant differences at $1000 \mu \mathrm{M}$ glyphosate between $\mathrm{R}$ and $\mathrm{S}$ accessions of Cuba ( $p=0.0013, D F=3, n=12)$ and Dominican Republic $(p=0.0008, D F=4, n=15)$. 
TABLE 2 | Parameters of the log-logistic equations used to calculate the glyphosate rates required for $50 \%$ survival (LD 50 ) and reduction fresh weight $\left(G_{50}\right)$ of the different accessions of $P$. hyterophorus from Cuba and Dominican Republic.

\begin{tabular}{|c|c|c|c|c|c|c|c|c|c|c|c|c|}
\hline \multirow[t]{2}{*}{ Accessions } & \multicolumn{6}{|c|}{ Survival ${ }^{\mathrm{a}}(\%)$} & \multicolumn{6}{|c|}{ Fresh weight reduction $^{b}(\%)$} \\
\hline & $d$ & $b$ & $R^{2}$ & $\operatorname{LD}_{50}(\mathrm{~g}$ ae ha-1) & $\mathbf{R I}$ & $p$ & $d$ & $b$ & $R^{2}$ & $\mathrm{GR}_{50}\left(\mathrm{~g}\right.$ ae ha $\left.{ }^{-1}\right)$ & $\mathbf{R I}$ & $p$ \\
\hline Cu-R1 & 99.8 & 6.1 & 0.98 & $6364 \pm 122$ & 27.5 & $<0.0001$ & 99.4 & 1.8 & 0.99 & $1370 \pm 191$ & 24.5 & $<0.0001$ \\
\hline Cu-R2 & 98.9 & 2.9 & 0.99 & $2794 \pm 90$ & 12.0 & $<0.0001$ & 103.0 & 1.5 & 0.95 & $437 \pm 28$ & 7.8 & $<0.0001$ \\
\hline Cu-R3 & 100.9 & 2.6 & 0.99 & $1415 \pm 55$ & 6.1 & $<0.0001$ & 103.3 & 1.3 & 0.96 & $151 \pm 13$ & 2.7 & 0.003 \\
\hline Cu-S & 102.7 & 3.1 & 0.97 & $232 \pm 23$ & - & - & 103.2 & 1.7 & 0.98 & $56 \pm 6$ & - & - \\
\hline Do-R1 & 100.1 & 5.1 & 0.96 & $4456 \pm 76$ & 22.7 & $<0.0001$ & 98.2 & 1.8 & 0.98 & $939 \pm 25$ & 20.0 & $<0.0001$ \\
\hline Do-R2 & 99.9 & 2.7 & 0.98 & $2550 \pm 92$ & 13.0 & $<0.0001$ & 99.6 & 1.8 & 0.99 & $547 \pm 30$ & 11.6 & $<0.0001$ \\
\hline Do-R3 & 100.7 & 1.7 & 0.99 & $1821 \pm 63$ & 9.3 & $<0.0001$ & 97.9 & 1.3 & 0.99 & $339 \pm 27$ & 7.2 & $<0.0001$ \\
\hline Do-R4 & 100.9 & 1.9 & 0.99 & $1242 \pm 65$ & 6.3 & $<0.0001$ & 96.4 & 1.3 & 0.96 & $255 \pm 33$ & 5.4 & $<0.0001$ \\
\hline Do-S & 100.5 & 4.5 & 0.97 & $196 \pm 8$ & - & - & 100.6 & 1.7 & 0.98 & $47 \pm 4$ & - & - \\
\hline
\end{tabular}

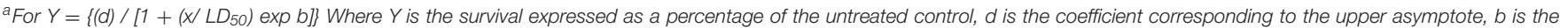
slope of the curve in $L D_{50}, L D_{50}$ is the herbicide rate at the point of inflection halfway, and $x$ is the herbicide dose.

${ }^{b}$ For $Y=(d) /\left[1+\left(x / G R_{50}\right)\right.$ exp b] Where $Y$ is the above-ground weight expressed as a percentage of the untreated control, $d$ is the coefficient corresponding to the upper asymptote, $b$ is the slope of the curve in $G R_{50}, G R_{50}$ is the herbicide rate at the point of inflection halfway, and $x$ is the herbicide dose.

TABLE $3 \mid{ }^{14} \mathrm{C}$-glyphosate absorption (\% of recovered radioactivity) and translocation (\% of absorbed radioactivity) in the different $P$. hysterophorus accessions at $96 \mathrm{~h}$ after treatment (HAT).

\begin{tabular}{lcccc}
\hline Accessions & $\begin{array}{c}\text { Absorption } \\
(\boldsymbol{p}=\mathbf{0 . 0 0 0 1}, \boldsymbol{D} \boldsymbol{F}=\mathbf{8}, \boldsymbol{n}=\mathbf{4 5})\end{array}$ & $\begin{array}{c}\text { Treated leaf } \\
(\boldsymbol{p}=\mathbf{0 . 0 0 0 3}, \boldsymbol{D} \boldsymbol{F}=\mathbf{8}, \boldsymbol{n}=\mathbf{4 5})\end{array}$ & $\begin{array}{c}\text { Rest of shoot } \\
(\boldsymbol{p}=\mathbf{0 . 0 0 0 1}, \boldsymbol{D} \boldsymbol{F}=\mathbf{8}, \boldsymbol{n}=\mathbf{4 5})\end{array}$ & $\begin{array}{c}\mathbf{R o o t} \\
(\boldsymbol{p}=\mathbf{0 . 0 0 0 4}, \boldsymbol{D} \boldsymbol{F}=\mathbf{8}, \boldsymbol{n}=\mathbf{4 5})\end{array}$ \\
\cline { 3 - 5 } & & $77.9 \pm 5.7 \mathrm{AB}$ & $12.1 \pm 2.1 \mathrm{BCD}$ & $10.0 \pm 2.3 \mathrm{BC}$ \\
Cu-R1 & $59.3 \pm 4.9 \mathrm{BC}$ & $82.4 \pm 4.2 \mathrm{~A}$ & $9.3 \pm 1.9 \mathrm{D}$ & $8.3 \pm 3.4 \mathrm{BCD}$ \\
Cu-R2 & $60.2 \pm 2.1 \mathrm{BC}$ & $80.1 \pm 3.9 \mathrm{AB}$ & $15.7 \pm 3.4 \mathrm{~B}$ & $4.2 \pm 1.2 \mathrm{D}$ \\
Cu-R3 & $56.8 \pm 3.9 \mathrm{C}$ & $35.5 \pm 2.3 \mathrm{C}$ & $41.6 \pm 6.2 \mathrm{~A}$ & $22.9 \pm 4.8 \mathrm{~A}$ \\
Cu-S & $82.2 \pm 6.7 \mathrm{~A}$ & $78.3 \pm 6.7 \mathrm{AB}$ & $10.5 \pm 2.7 \mathrm{CD}$ & $11.2 \pm 2.1 \mathrm{~B}$ \\
Do-R1 & $63.1 \pm 6.8 \mathrm{~B}$ & $79.3 \pm 3.4 \mathrm{AB}$ & $16.2 \pm 4.9 \mathrm{~B}$ & $4.5 \pm 1.4 \mathrm{D}$ \\
Do-R2 & $55.9 \pm 7.8 \mathrm{C}$ & $75.6 \pm 5.1 \mathrm{~B}$ & $14.1 \pm 3.8 \mathrm{BC}$ & $10.3 \pm 3.8 \mathrm{~B}$ \\
Do-R3 & $60.4 \pm 3.7 \mathrm{BC}$ & $81.4 \pm 6.3 \mathrm{~A}$ & $12.7 \pm 4.3 \mathrm{BCD}$ & $3.9 \pm 2.7 \mathrm{CD}$ \\
Do-R4 & $58.4 \pm 2.3 \mathrm{BC}$ & $39.1 \pm 1.9 \mathrm{C}$ & $37.8 \pm 2.3 \mathrm{~A}$ & $23.1 \pm 5.6 \mathrm{~A}$ \\
Do-S & $78.8 \pm 5.6 \mathrm{~A}$ & &
\end{tabular}

a Over $95 \%$ of the total radioactivity applied was recovered.

Mean value $(n=5) \pm$ standard error. Means on a same column followed by the same letter were not significantly different at $\alpha=0.05$.

There were marked differences in glyphosate absorption between the resistant and susceptible glyphosate P. hysterophorus accessions at $96 \mathrm{~h}$ after treatment $(\mathrm{HAT})(p=0.0001, D F=8$, $n=45$ ) (Table 3). All accessions obtain maximum absorption at $96 \mathrm{HAT}$, and the two susceptible accessions absorbed an average of $80.5 \%$, while the resistance accessions absorbed an average of $59.2 \%$ of ${ }^{14} \mathrm{C}$-glyphosate which was recovered.

Translocation assays suggest marked differences at 96 HAT between the $\mathrm{Cu}-\mathrm{S}$ and Do-S accessions compared to the $\mathrm{Cu}$ R1, Cu-R2, Cu-R3, Do-R1, Do-R2, Do-R3, and Do-R4 ones in treated leaf $(p=0.0003, D F=8, n=45)$, rest of the shoots $(p=$ $0.0001, D F=8, n=45)$, and root $(p=0.0004, D F=8, n=45)$ (Table 3). There were no significant differences in translocation between the two susceptible accessions (Cu-S and Do-S) from Caribbean Islands. But there were small significant differences in the resistant accessions (Cu-R1, Cu-R2, Cu-R3, Do-R1, Do-R2,
Do-R3, and Do-R4). Nonetheless, the high amount of ${ }^{14} \mathrm{C}-$ glyphosate in each resistant accession remained in the treated leaf. Due to differences in levels of glyphosate resistance between the $P$. hysterophous resistant accessions, we suspect that other mechanisms could be involved (Tables 2, 3, Figure 3).

\section{Biochemical Studies}

Previous tests demonstrated that the highest glyphosate translocation and metabolism was reached at 96 HAT in the $P$. hysterophorus accessions (unpublished data). There were significant differences at 96 HAT in glyphosate metabolism levels between accessions ( $p=0.0014, D F=8, n=36$ ). Glyphosate levels decreased, whereas glyphosate metabolites (AMPA, glyoxylate and sarcosine) increased at 96 HAT in the $\mathrm{Cu}-\mathrm{R} 1$, Do-R1, Do-R2, Cu-R2, and Do-R3 accessions. Higher glyphosate levels remained in the $\mathrm{Cu}-\mathrm{R} 3$ and Do-R4 (low resistance), and 


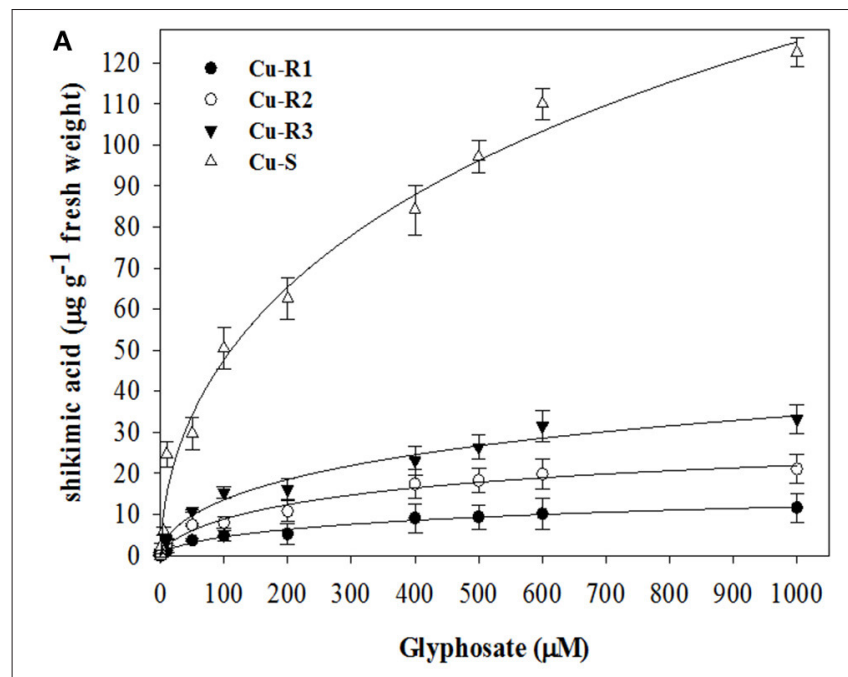

B

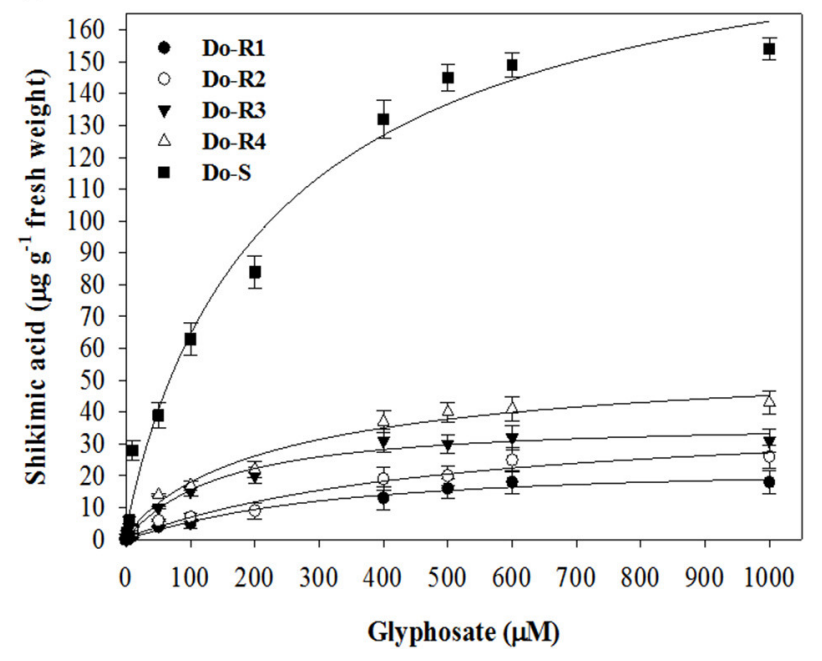

FIGURE 3 | Shikimic acid accumulation in leaf segments of plants from Cuba (A) and Dominican Republic (B) accessions of $P$. hysterophorus. Symbols denoted mean $(n=3) \pm$ standard errors of the mean.

very high one in the $\mathrm{Cu}-\mathrm{S}$ and Do-S (susceptible) accessions. In these last accessions, sarcosine was not detected (Table 4). These results can also explain the low level of resistance of the accession (Cu-R3 and Do-R4) with a single resistance mechanism, while the other glyphosate resistant accessions have at least two mechanisms (Tables 3, 4).

The EPSPS enzymes of all the accession plants were inhibited by glyphosate. The $\mathrm{I}_{50}$ (herbicide dose which reduces the enzyme activity to 50\%) values were different in all accessions, ranging between approximately 47.65 in Cu-R1, 25.2 in Do-R1, 22.1 in Do-R2, 1.4 in Cu-R2, 1.2 in Do-R3, 1.2 in the Cu-R3, and 1.1-fold resistance in Do-R4 accessions relative to their susceptible accession, respectively (Figure 4, Table 5). These results were in accordance with the in vivo resistance level shown for the different accessions, and suggest that multiple mechanisms in the target-site could be expressed in these accessions.

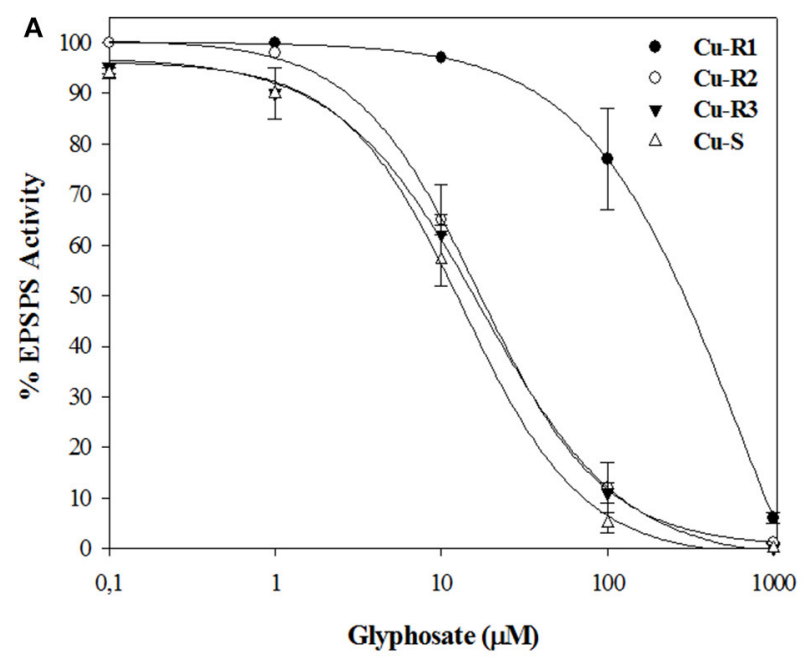

B

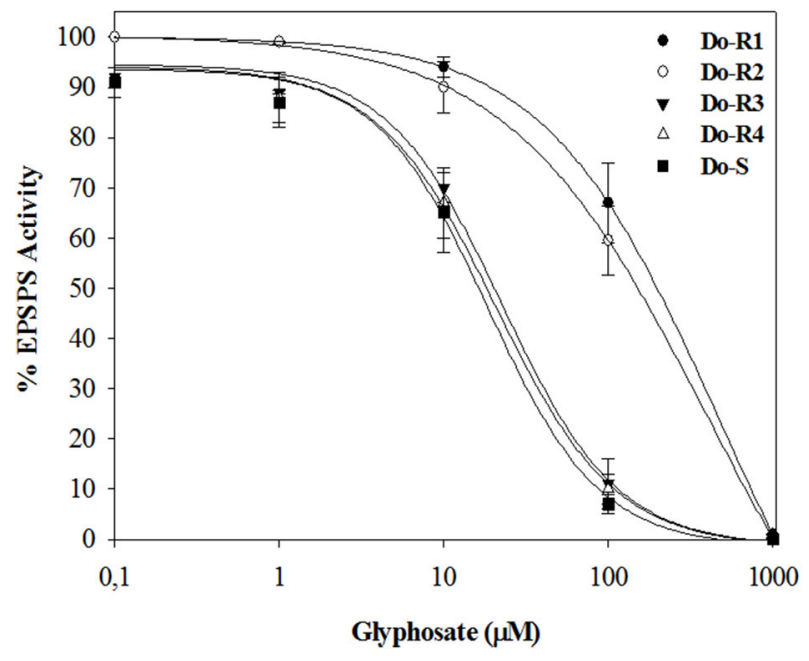

FIGURE 4 | EPSPS enzyme activity expressed as percentage of the untreated control in leaf extracts of plants from Cuba (A) and Dominican Republic (B) accessions of $P$. hysterophorus. Symbols denoted mean $(n=3)$ \pm standard errors of the mean.

The basal activity of EPSPS enzyme (without glyphosate) in the resistant accessions was between 0.026 and $0.21 \mu \mathrm{mol} \mu \mathrm{g}^{-1}$ protein $\mathrm{min}^{-1}$, while the susceptible accessions (Cu-S and Do-S) were lower with 0.024 and $0.025 \mu \mathrm{mol} \mu \mathrm{g}^{-1}$ protein $\mathrm{min}^{-1}$, respectively (Figure 5). There were market differences between accessions in both Cuba $(p=0.0001, D F=3, n=12)$, and Dominican Republic ( $p=0.0002, D F=4, n=15)$. The Cu-R1, Do-R1, and Do-R2 exhibited 8.8, 7.2, and 4.8-times higher basal enzyme activities than their susceptible accessions, respectively. For $\mathrm{Cu}-\mathrm{R} 2, \mathrm{Do}-\mathrm{R} 3, \mathrm{Do}-\mathrm{R} 4$, and $\mathrm{Cu}-\mathrm{R} 3$ accessions the values were similar to those found for their susceptible accessions, respectively.

\section{Molecular Studies}

A total of $462 \mathrm{bp}$ of the EPSPS gene of P. hysterophorus plants of resistant and susceptible accessions were sequenced. The fragments were aligned and numbered based on a published 
TABLE 4 | Glyphosate metabolism expressed as a percentage of total glyphosate and its metabolites in $P$. hystherophorus susceptible and resistant-glyphosate accessions at 96 HAT.

\begin{tabular}{|c|c|c|c|c|}
\hline \multirow[t]{2}{*}{ Accessions } & \multirow{2}{*}{$\begin{array}{c}\text { Glyphosate } \\
(p=0.0014, D F=8, n=36)\end{array}$} & \multicolumn{3}{|c|}{ Metabolites } \\
\hline & & $\begin{array}{c}\text { AMPA } \\
(p=0.0003, D F=8, n=36)\end{array}$ & $\begin{array}{c}\text { Glyoxylate } \\
(p=0.0001, D F=8, n=36)\end{array}$ & $\begin{array}{c}\text { Sarcosine } \\
(p=0.0002, D F=8, n=36)\end{array}$ \\
\hline Cu-R1 & $9.80 \pm 1.70 \mathrm{D}$ & $60.54 \pm 1.32 \mathrm{~B}$ & $18.14 \pm 0.32 \mathrm{C}$ & $11.52 \pm 0.96 \mathrm{~A}$ \\
\hline Cu-R2 & $21.12 \pm 0.93 C$ & $55.31 \pm 1.57 \mathrm{~B}$ & $20.80 \pm 0.51 \mathrm{AB}$ & $2.77 \pm 0.31 \mathrm{E}$ \\
\hline Cu-R3 & $73.42 \pm 3.63 B$ & $26.14 \pm 0.26 \mathrm{C}$ & $0.44 \pm 0.02 \mathrm{E}$ & ND \\
\hline Cu-S & $91.82 \pm 4.81 \mathrm{~A}$ & $7.68 \pm 0.33 E$ & $0.50 \pm 0.02 \mathrm{E}$ & ND \\
\hline Do-R1 & $11.83 \pm 0.74 \mathrm{D}$ & $58.94 \pm 2.79 B$ & $21.74 \pm 0.97 \mathrm{~A}$ & $7.49 \pm 0.27 C$ \\
\hline Do-R2 & $11.37 \pm 0.80 \mathrm{D}$ & $64.70 \pm 2.93 \mathrm{~A}$ & $18.54 \pm 0.83 \mathrm{C}$ & $5.39 \pm 0.15 \mathrm{D}$ \\
\hline Do-R3 & $9.56 \pm 0.72 \mathrm{D}$ & $60.95 \pm 2.71 \mathrm{~B}$ & $20.36 \pm 0.94 \mathrm{~B}$ & $9.13 \pm 0.53 B$ \\
\hline Do-R4 & $71.21 \pm 1.06 \mathrm{~B}$ & $20.05 \pm 2.20 \mathrm{D}$ & $7.28 \pm 0.93 \mathrm{D}$ & $1.01 \pm 0.71 \mathrm{~F}$ \\
\hline Do-S & $90.68 \pm 4.39 A$ & $8.86 \pm 1.06 \mathrm{E}$ & $0.46 \pm 0.03 E$ & ND \\
\hline
\end{tabular}

Mean value $(n=4) \pm$ standard error. Means on a same column followed by the same letter were not significantly different at $\alpha=0.05$.

ND, non-detected; AMPA, aminomethylphosphonic acid.

EPSPS sequence of Arabidopsis thaliana (L.) Heynh. (GenBank: CAA29828.1). The resistant accessions of $P$. hysterophorus $\mathrm{Cu}-$ R1 from Cuba, and Do-R1 and Do-R2 from Dominican Republic, showed an amino acid substitution at position 106 consisting of a Proline to Serine (Figure 6).

\section{DISCUSSION}

P. hysterophorus is universally recognized for its widespread distribution and high seed production, commonly known as the parthenium weed. Parker (1989) identified two biotypes with different flowering patterns in Mexico (Caribbean area), and they were genetically distinct biotypes (Clermont and Toogoolawah). Moreover, Hanif et al. (2011) found that these two biotypes differed in their morphology and reproductive behavior; in particular, the Toogoolawah biotype shows a greater tendency toward self-pollination, but these biotypes can also present outcrossing. It makes sense that it would reproduce prolifically and that higher resistance levels due to accumulation of multiple mechanisms, by multiple crossings, would proliferate within populations (Table 6).

Glyphosate has been used repeatedly in perennial crop areas and fallow fields in the Caribbean Islands for many years to manage $P$. hysterophorus and other troublesome weeds. However, using glyphosate alone without any additional alternative and/or IWM (Integrated Weed Management) led to the emergence of glyphosate-resistant weeds early in the second decade of the 21st century (Tables 1, 2). Herbicide response between different locations depends on local ecological factors, such as a variation in soil type, tillage practices, types of crops, fertilizers, etc., (Shaner and Beckie, 2014; Jussaume and Ervin, 2016). Our results showed different glyphosate resistance levels between the $P$. hysterophorus accessions. This differences could be addressed to the use of different glyphosate formulations and dose rate, the application technique (manual or mechanical) employed by farmers, and the agro environment conditions (Neve et al.,
TABLE 5 | Parameter estimates of the equation used to calculate the sensitivity of EPSPS enzyme activity to glyphosate in extracts from leaf tissue of the different accessions of $P$. hyterophorus from Cuba and Dominican Republic.

\begin{tabular}{lcccccc}
\hline Accessions & $\boldsymbol{d}$ & $\boldsymbol{b}$ & $\boldsymbol{R}^{\mathbf{2}}$ & $\mathbf{I}_{\mathbf{5 0}}(\boldsymbol{\mu} \mathbf{M})^{\mathbf{a}}$ & $\mathbf{R I}$ & $\boldsymbol{P}$ \\
\hline Cu-R1 & 100.1 & 0.9 & 0.97 & $646.2 \pm 35.8$ & 47.6 & $<0.0001$ \\
Cu-R2 & 99.8 & 0.8 & 0.96 & $18.9 \pm 1.4$ & 1.4 & 0.1902 \\
Cu-R3 & 97.0 & 1.0 & 0.99 & $17.4 \pm 2.8$ & 1.2 & 0.2186 \\
Cu-S & 96.2 & 1.2 & 0.98 & $13.6 \pm 2.2$ & - & - \\
Do-R1 & 100.0 & 0.8 & 0.99 & $468.1 \pm 22.0$ & 25.2 & $<0.0001$ \\
Do-R2 & 100.4 & 0.7 & 0.99 & $410.7 \pm 26.1$ & 22.1 & $<0.0001$ \\
Do-R3 & 94.5 & 1.2 & 0.98 & $22.6 \pm 1.5$ & 1.2 & 0.3714 \\
Do-R4 & 94.0 & 1.2 & 0.96 & $20.8 \pm 6.1$ & 1.1 & 0.6042 \\
Do-S & 93.6 & 1.2 & 0.99 & $18.5 \pm 5.7$ & - & -
\end{tabular}

${ }^{a}$ For $Y=\left\{(d) /\left[1+\left(x / I_{50}\right)\right.\right.$ exp b]\} Where $Y$ is the EPSPS activity, $d$ is the coefficient corresponding to the upper asymptote, $b$ is the slope of the curve in $I_{50}, I_{50}$ is the herbicide rate at the point of inflection halfway, and $x$ is the herbicide dose.

2014; Renton et al., 2014; Jussaume and Ervin, 2016; Matzrafi et al., 2016; Owen, 2016). It has been shown that an increase in the relative humidity and temperature increases the glyphosate absorption, translocation, and toxicity in many weed species (Ge et al., 2011; Hatterman-Valenti et al., 2011; Vila-Aiub et al., 2012; Santos et al., 2016). This research also revealed that the low $\mathrm{GR}_{50}$ and $\mathrm{LD}_{50}$ values for the susceptible accessions showed that glyphosate has been a very effective tool for farmer for over 15 years, as has been shown in $P$. hysterophorus from Colombia, Dominican Republic, and Florida (Fernandez, 2013; Rosario et al., 2013; Jimenez et al., 2014).

Plants with low levels of $\mathrm{GR}_{50}$ and $\mathrm{LD}_{50}$ are related to an increased inhibition of EPSPS activity and a greater accumulation of shikimic acid (Shaner et al., 2005; Gaines et al., 2010; Fernández et al., 2015). High levels of resistance (RI) and low shikimic acid accumulation observed in the different $P$. hystherophorus accessions were consistent with those of plants 
which have acquired resistance to the addition of more than one NTSR and/or TSR mechanisms, as has been shown in dicotyledonous weed species such as Amaranthus tuberculatus (Nandula et al., 2013), Conyza sumatrensis (González-Torralva et al., 2014), and several grass weed species (Michitte et al., 2007; de Carvalho et al., 2012; Fernández et al., 2015).

According to Shepherd and Griffiths (2006), a cuticular wax layer provides a protective barrier for a wide range of abiotic stresses (pesticide). Resistant and tolerant plants have displayed a cuticle containing a massive amount of epicuticular wax which forms a nonuniform 3D cover as has been revealed by scanning electron micrographs (De Prado et al., 2005; Wang and Liu, 2007; Rojano-Delgado et al., 2012; Alcántara-de la Cruz et al., 2016a). The limited glyphosate absorption by the resistant $P$. hysterophorus accessions was likely to have been due to differences in outer leaf surfaces. Different translocation can be explained by ${ }^{14} \mathrm{C}$-glyphosate and/or its metabolite accumulation in the tips of the resistant treated leaves, while ${ }^{14} \mathrm{C}$ was removed from the susceptible treated leaves (Table 3). Since the first case of glyphosate resistance was detected in a population of Lolium rigidum in Australia (Powles et al., 1998), both previously mentioned mechanisms were considered responsible for this resistance (Wakelin et al., 2004; Michitte et al., 2007; Preston and Wakelin, 2008; de Carvalho et al., 2012; González-Torralva et al., 2012, 2014; Nandula et al., 2013; Fernández et al., 2015). Subsequent studies in the main dicot and monocotyledonous glyphosate-resistant weeds seem to have demonstrated that the main NTSR mechanism involved in their resistance is due to a lesser glyphosate absorption and/or -translocation (Feng et al., 2004; Michitte et al., 2007; de Carvalho et al., 2012; GonzálezTorralva et al., 2012, 2014; Vila-Aiub et al., 2012; Nandula et al., 2013; Adu-Yeboah et al., 2014).

In some plants, the glyphosate degradation to glyoxylate and AMPA is carried out by a glyphosate oxidoreductase (GOX), and the glyphosate degradation to sarcosine and inorganic phosphate by a C-P lyase. These steps have been reported by some authors such as Liu et al. (1991); Komoba et al. (1992); Saroha et al. (1998); Al-Rajab and Schiavon (2010), and Duke (2012) among others. However, only a few works unify these two degradation pathways to explain the glyphosate metabolism in leguminous plants and weeds (de Carvalho et al., 2012; Rojano-Delgado et al., 2012). Some authors consider that metabolism has a low contribution to the resistance or, even more, that it is nonexistent (Saroha et al., 1998; Feng et al., 2004; Duke, 2012; Sammons and Gaines, 2014). However, the fact is that this mechanism involves a decrease in the concentration of the herbicide glyphosate around the target-site, diminishing the EPSPS inhibition rate (Duke, 2012; Sammons and Gaines, 2014; Alcántara-de la Cruz et al., 2016a). The GOX gene that encodes the glyphosate metabolizing enzyme glyphosate oxidoreductase was cloned from Achromobacter sp. strain LBAA (Barry et al., 1994). Neither plant GOX nor the gene(s) encoding it have been isolated or elucidated. A plant gene encoding GOX might be useful in genetically engineering crops and weed resistance development (Duke, 2012; RojanoDelgado et al., 2012). Some researchers have proposed additive effects of concurrent glyphosate resistance mechanisms in the

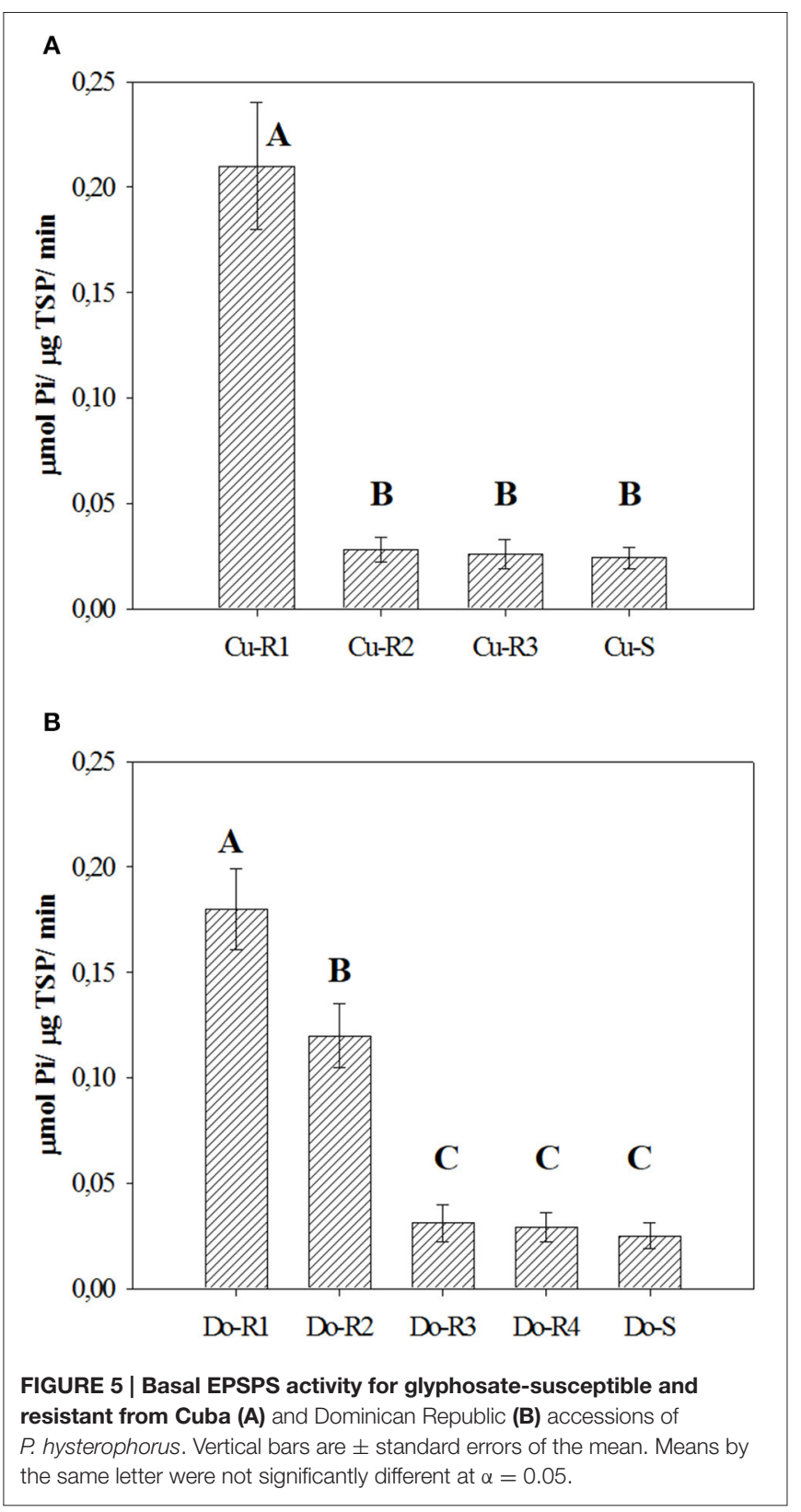

same weed species (Gaines et al., 2010; Yu et al., 2010; Bostamam et al., 2012; Rojano-Delgado et al., 2012), which would explain the difference in the resistance between accessions keeping the same percentage of metabolic degradation (Table 6). However, genetic basic controlling absorption/translocation and/or metabolism including genes involved have not been identified so far (Yuan et al., 2006; Delye, 2013; Délye et al., 2013). This could be a highly promising research area in the future.

Taking into account these results, resistance could be associated with target enzyme overexpression. Some species as ryegrass (Yu et al., 2007; Dayan et al., 2012) have shown differences in the basal EPSPS enzyme activity as a consequence of the EPSPS gene overexpression. However, in the L. perenne spp. multiflorum population from Arkansas, no differences were 


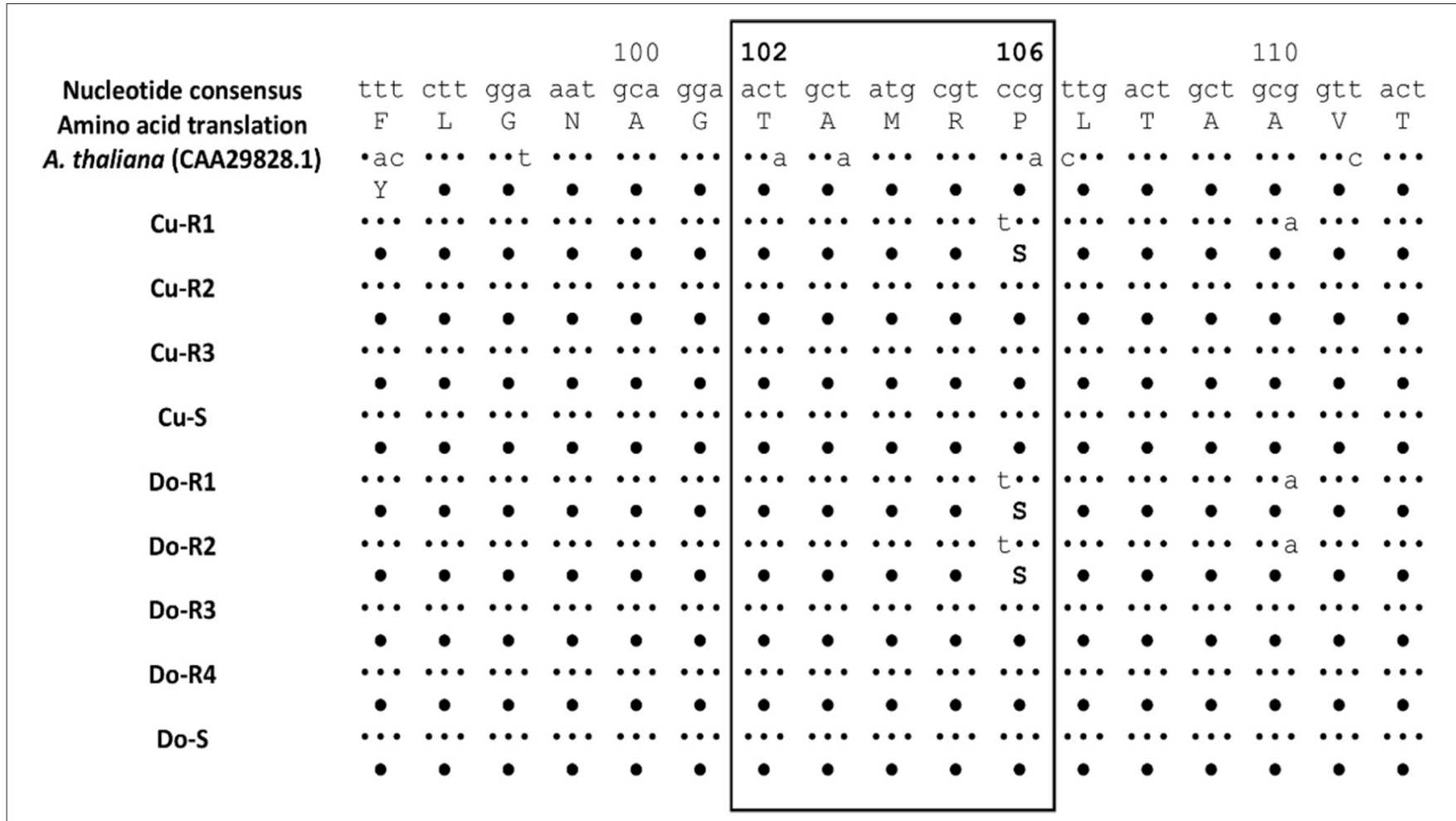

FIGURE 6 | Partial protein sequence alignment of the EPSPS gene of resistant and susceptible $\boldsymbol{P}$. hysterophorus plants. The box comprising the region of Thr-102 and Pro-106 point mutations associated to confer glyphosate resistance. The points indicate homology between the different sequences.

TABLE 6 | Summary of glyphosate resistance mechanisms accumulated by $P$. hysterophorus accessions studied in this work.

\begin{tabular}{|c|c|c|c|c|c|c|c|}
\hline Accessions & $\mathrm{GR}_{50}{ }^{\mathrm{a}}$ & $\operatorname{LD}_{50}{ }^{a}$ & Absorption and translocation & Glyphosate metabolism & Enhanced EPSPS basal activity ${ }^{b}$ & EPSPS $\left(l_{50}{ }^{b}\right)$ & Pro106Ser \\
\hline Cu-R1 & 1370 & 6364 & Low & High & Yes & High & Yes \\
\hline Cu-R2 & 437 & 2794 & Low & High & No & Low & No \\
\hline Cu-R3 & 151 & 1415 & Low & Medium & No & Low & No \\
\hline Cu-S & 56 & 232 & High & Low & No & Low & No \\
\hline Do-R1 & 939 & 4456 & Low & High & Yes & High & Yes \\
\hline Do-R2 & 547 & 2550 & Low & High & Yes & High & Yes \\
\hline Do-R3 & 339 & 1821 & Low & High & No & Low & No \\
\hline Do-R4 & 255 & 1242 & Low & Medium & No & Low & No \\
\hline Do-S & 47 & 196 & High & Low & No & Low & No \\
\hline
\end{tabular}

${ }^{a}$ glyphosate $g$ ae $h a^{-1} ;{ }^{b}$ glyphosate $\mu \mathrm{M}$.

observed in the $\mathrm{I}_{50}$ values, which could be explained as a lack of effective mutations in the binding site of the enzyme (Salas et al., 2015). In our case, some accessions are candidates to possessing an effective mutation (Figure 6, Table 6) or a possible EPSPS overexpression, explaining their high resistance to glyphosate compared to other accessions. We are aware of that fact, and effective research is currently in progress to characterize the EPSPS overexpression resistance mechanism involving these accessions.

Results reported here are in agreement with previous works, in which the Proline to Serine substitution was found to confer glyphosate resistance in other weed species such as
A. tuberculatus, C. sumatrensis, Echinochloa colona; L. perenne spp. multiflorum and L. rigidum (Bostamam et al., 2012; González-Torralva et al., 2012, 2014; Nandula et al., 2013; Fernández et al., 2015; Han et al., 2016). However, mutations in the Pro-106 position generally provide only a low level (24-fold) of glyphosate resistance (Kaundun et al., 2011). Here, $P$. hysterophorus accessions that presented Pro-106 mutation had a resistance factor of $>12$. These three accessions $(\mathrm{Cu}-\mathrm{R} 1, \mathrm{Do}-\mathrm{R} 1$, and Do-R2) were more highly resistant to glyphosate as a result of showing different concurrent resistance mechanisms, including reduced absorption and translocation, glyphosate metabolism, and EPSPS gene mutation. 
In some species, at least more than one glyphosate resistance mechanism have been reported, such as $A$. tuberculatus (Nandula et al., 2013), L. rigidum (Bostamam et al., 2012), L. perenne spp. multiflorum (González-Torralva et al., 2012), and L. perenne (Ghanizadeh et al., 2015) populations which exhibited a mutation in Pro-106 position, and a reduced translocation. Besides, other species such as Digitaria insularis presented a pool of mechanisms (absorption, translocation, metabolism, and EPSPS gene mutation; de Carvalho et al., 2012). The involvement of several resistance mechanisms is evident when looking at the resistance levels of accessions $\mathrm{Cu}-\mathrm{R} 2, \mathrm{Cu}-\mathrm{R} 3, \mathrm{Cu}-\mathrm{R} 4, \mathrm{Do}-\mathrm{R} 3, \mathrm{Do}-\mathrm{R} 4$, and Do-R5 of $P$. hysterophorus, which did not show any mutation in the Pro-106 position. This is the first time that a mutation in the target-site has been reported in glyphosate-resistant P. hysterophorus.

In summary, we have confirmed resistance to glyphosate in different $P$. hysterophorus accessions harvested in the Caribbean Islands. Their resistance levels depend on the different resistance mechanisms (NTSR and TSR) that are accumulated by these accessions (Table 6), due to increasing selection pressure and out-crossing. The evolution of multiple mechanisms found in this resistance species is worrying. The farmers should implement manage practices such as the use of cover crops, which prevent soil erosion and allow the use of grazing, as well as the use of other

\section{REFERENCES}

Adkins, S., and Shabbir, A. (2013). Biology, ecology and management of the invasive parthenium weed (Pathenium hysterophorus L.). Pest Manag. Sci. 70, 1023-1029. doi: 10.1002/ps.3708

Adu-Yeboah, P., Malone, J. M., Gill, G., and Preston, C. (2014). Reduced glyphosate translocation in two glyphosate-resistant populations of rigid ryegrass (Lolium rigidum) from fence lines in South Australia. Weed Sci. 62, 4-10. doi: 10.1614/WS-D-13-00072.1

Alcántara-de la Cruz, R., Barro, F., Domínguez-Valenzuela, J. A., and De Prado, R. (2016a). Physiological, morphological and biochemical studies of glyphosate tolerance in Mexican Cologania (Cologania broussonetii (Balb.) DC.). Plant Physiol. Biochem. 98, 72-80. doi: 10.1016/j.plaphy.2015.11.009

Alcántara-de la Cruz, R., Fernández-Moreno, P. T., Ozuna, C. V., Rojano-Delgado, A. M., Cruz-Hipolito, H. E., Domínguez-Valenzuela, J. A., et al. (2016b). Target and non-target site mechanisms developed by glyphosate-resistant Hairy beggarticks (Bidens pilosa L.) populations from Mexico. Front. Plant Sci. 7:1492. doi: 10.3389/fpls.2016.01492

Al-Rajab, A., and Schiavon, M. (2010). Degradation of ${ }^{14} \mathrm{C}$-glyphosate and aminomethylphosphonic acid (AMPA) in three agricultural soils. J. Environ. Sci. 22, 1374-1380. doi: 10.1016/S1001-0742(09)60264-3

Amrhein, N., Deus, B., Gehrke, P., and Steinrücken, H. C. (1980). The site of the inhibition of shikimate pathway by glyphosate. Plant Physiol. 66, 830-834. doi: $10.1104 /$ pp.66.5.830

Barry, G. F., Taylor, M. L., Padgette, S. R., Kolaz, K. H., Hallas, L. E., della-Cioppa, G., et al. (1994). Cloning and Expression in Echerichia coli of the Glyphosate to Aminomethylphosphonic Acid Degrading Activity from Achromobacter sp. Strain LBAA. Monsanto Technical Report MSL-13245, St. Louis, MO.

Bostamam, Y., Malone, J. M., Dolman, F. C., Boutsalis, P., and Preston, C. (2012). Rigid ryegrass (Lolium rigidum) populations containing a target site mutation in EPSPS and reduced glyphosate translocation are more resistant to glyphosate. Weed Sci. 60, 474-479. doi: 10.1614/WS-D-11-00154.1

Bradford, M. M. (1976). A rapid and sensitive method for the quantitation of microgram quantities of protein utilizing the principle of protein dye binding. Anal. Biochem. 72, 248-254. doi: 10.1016/0003-2697(76)90527-3 non-selective herbicides in an integrated weed management (IWM) to facilitate the reduction and suppression of herbicideresistant accessions.

\section{AUTHOR CONTRIBUTIONS}

$\mathrm{EB}, \mathrm{PF}$, and RD performed the glyphosate plant dose-response and shikimic acid accumulation. $\mathrm{EB}, \mathrm{PF}, \mathrm{FB}$, and $\mathrm{RD}$ carried out the EPSPS activity assays. EB, PF, and RD did the ${ }^{14} \mathrm{C}$-glyphosate absorption/translocation, and metabolism study. FB performed the EPSP synthase gene sequencing.

\section{FUNDING}

This work was funded by AGL2013-48946-C3-1-R and AGL2016-78944-R projects (Spain).

\section{ACKNOWLEDGMENTS}

The authors would like to thank Dr. J. Cueto (Cuba) and Dr. F. Jimenez (Dominican Republic) to help Dr. De Prado to harvest the seed accessions. We would also like to thank R. RoldanGómez for the technical help and Dr. R. Alcantara de la Cruz and Dr. A. M. Rojano-Delgado for their assistance with the experiments and for their insightful comments.
Burgos, N. R., Tranel, P. J., Streibig, J. C., Davis, V. M., Shaner, D., Norsworthy, J. K., et al. (2013). Review: confirmation of resistance to herbicides and evaluation of resistance levels. Weed Sci. 61, 4-20. doi: 10.1614/WS-D-12-00032.1

Busi, R., Vila-Aiub, M. M., and Powles, S. B. (2011). Genetic control of a cytochrome $\mathrm{P}_{450}$ metabolism-based herbicide resistance mechanism in Lolium rigidum. Heredity 106, 817-824. doi: 10.1038/hdy.2010.124

Cruz-Hipólito, H. E., Rojano-Delgado, A., Domínguez-Valenzuela, J. A., Heredia, A., Luque-de Castro, M. D., and De Prado, R. (2011). Glyphosate tolerance by Clitoria ternatea and Neonotonia wightii plants involves differential absorption and translocation of the herbicide. Plant Soil. 347, 221-230. doi: 10.1007/s11104-011-0840-9

Cruz-Hipólito, H., Osuna, M. D., Heredia, A., Ruiz-Santaella, J. P., and De Prado, R. (2009). Non target mechanism involved in glyphosate tolerance found in Canavalia ensiformis plants. J. Agric. Food Chem. 57, 4844-4848. doi: $10.1021 /$ jf9003253

Dayan, F. E., Owens, D. K., Corniani, N., Lima-Silva, F. M., Watson, S. B., Howell, J. L., et al. (2015). Biochemical markers and enzyme assays for herbicide mode of action and resistance studies. Weed Sci. 63, 23-63. doi: 10.1614/WS-D-13-00063.1

Dayan, F. E., Owens, D. K., and Duke, S. O. (2012). Rationale for a natural products approach to herbicide discovery. Pest Manag. Sci. 68, 519-528. doi: $10.1002 / \mathrm{ps} .2332$

de Carvalho, L. B., Alves, P., Gonzalez-Torralva, F., Cruz-Hipolito, H. E., RojanoDelgado, A. M., De Prado, R., et al. (2012). Pool of resistance mechanisms to glyphosate in Digitaria insularis. J. Agric. Food Chem. 60, 615-622. doi: $10.1021 /$ jf204089d

Delye, C. (2013). Unravelling the genetic bases of non-target-site-based resistance (NTRS) to herbicides: a major challenge for weed science in the forthcoming decade. Pest Manag. Sci. 69, 176-187. doi: 10.1002/ps.3318

Délye, C., Jasieniuk, M., and Le Corre, V. (2013). Deciphering the evolution of herbicide resistance in weeds. TRENDS Genet. 29, 649-658. doi: 10.1016/j.tig.2013.06.001

De Prado, J. L., Osuna, M. D., Heredia, A., and De Prado, R. (2005). Lolium rigidum, a pool of resistance mechanisms to ACCase inhibitor herbicides. J. Agric. Food Chem. 53, 2185-2191. doi: 10.1021/jf049481m 
De Prado, R., and Franco, A. R. (2004). Cross-resistance and herbicide metabolism in grass weeds in Europe: biochemical and physiological aspects. Weed Sci. 52, 115-120. doi: 10.1614/P2002-168A

Duke, S. O. (2012). "Glyphosate metabolism in plantas," in Glyphosate. Uso Sustentável, eds E. Velini, C. A. Carbonari, D. K. Meschede, and M. L. BuenoTrindade (Botucatu: FEPAF), 17-38.

Evans, J. A., Tranel, P. J., Hager, A. G., Schutte, B., Wu, C., Chatham, L. A., et al. (2016). Managing the evolution of herbicide resistance. Pest Manag. Sci. 72, 74-80. doi: 10.1002/ps.4009

Feng, P. C. C., Tran, M., Chiu, T., Sammons, R. D., Heck, G. R., and CaJacob, C. A. (2004). Investigations into glyphosate resistant horseweed (Conyza canadensis): retention, uptake, translocation, and metabolism. Weed Sci. 52, 498-505. doi: 10.1614/WS-03-137R

Fernandez, J. V. (2013). Characterization of Glyphosate Resistance and Management of Ragweed Parthenium (Parthenium hysterophorus L.) in the Everglades Agricultural Area of Florida. Gainesville, FL: University of Florida.

Fernández, P., Alcántara, R., Osuna, M. D., Vila-Aiub, M. M., and De Prado, R. (2016). Forward selection for multiple resistance across the non-selective glyphosate, glufosinate and oxyfluorfen herbicides in Lolium weed species. Pest Manag. Sci. doi: 10.1002/ps.4368. [Epub ahead of print].

Fernández, P., Gauvrit, C., Barro, F., Menendez, J., and De Prado, R. (2015). First case of glyphosate resistance in France. Agron. Sustain. Dev. 35, 1469-1476. doi: 10.1007/s13593-015-0322-1

Franz, J. E., Mao, M. K., and Sikorski, J. A. (1997). Glyphosate: a unique global herbicide. Washington, DC: ACS American Chemical Society.

Gaines, T. A., Zhang, W., Wang, D., Bukun, B., Chisholm, S. T., Shaner, D. L., et al. (2010). Gene amplification confers glyphosate resistance in Amaranthus palmeri. Proc. Natl. Acad. Sci. U.S.A. 107, 1029-1034. doi: 10.1073/pnas.0906649107

Ge, X., d'Avignon, D. A., Ackerman, J. J., Duncan, B., Spaur, M. B., and Sammons, R. D. (2011). Glyphosate-resistant horseweed made sensitive to glyphosate: low-temperature suppression of glyphosate vacuolar sequestration revealed by ${ }^{31}$ P NMR. Pest Manag. Sci. 67, 1215-1221. doi: 10.1002/ps.2169

Ge, X., d'Avignon, D. A., Ackerman, J. J. H., Collavo, A., Sattin, M., Ostrander, E. L., et al. (2012). Vacuolar glyphosate-sequestration correlates with glyphosate resistance in ryegrass (Lolium spp.) from Australia, South America and Europe: a 31P-NMR investigation. J. Agric. Food Chem. 60, 1243-1250. doi: $10.1021 /$ jf203472s

Ghanizadeh, H., Harrington, K. C., James, T. K., Woolley, D. J., and Ellison, N. W. (2015). Mechanisms of glyphosate resistance in two perennial ryegrass (Lolium perenne) populations. Pest Manag. Sci. 71, 1617-1622. doi: 10.1002/ps.3968

González-Torralva, F., Gil-Humanes, J., Barro, F., Brants, I., and De Prado, R. (2012). Target site mutation and reduced translocation are present in a glyphosate-resistant Lolium multiflorum Lam. biotype from Spain. Plant Physiol. Biochem. 58, 16-22. doi: 10.1016/j.plaphy.2012.06.001

González-Torralva, F., Gil-Humanes, J., Barro, F., Domínguez-Valenzuela, J. A., and De Prado, R. (2014). First evidence for a target site mutation in the EPSPS2 gene in glyphosate-resistant Sumatran fleabane from citrus orchards. Agron. Sustain. Dev. 34, 553-560. doi: 10.1007/s13593-013-0163-8

Han, H., Yu, Q., Widderick, M. J., and Powles, S. B. (2016). Target-site EPSPS Pro-106 mutations: sufficient to endow glyphosate resistance in polyploid Echinochloa colona? Pest Manag. Sci. 72, 264-271. doi: 10.1002/ps.4038

Hanif, Z., Adkins, S. W., Prentis, P. J., Navie, S. C., and O’Donnell, C. (2011). "Characterization of the reproductive behaviour and invasive potential of parthenium weed in australia," in 23rd Asian-Pacific Weed Science Society Conference (Cairns, QLD), 49-55.

Hanson, B. D., Shrestha, A., and Shaner, D. L. (2009). Distribution of glyphosate-resistant horseweed (Conyza canadensis) and relationship to cropping systems in the central valley of California. Weed Sci. 57, 48-53. doi: 10.1614/WS-08-103.1

Hatterman-Valenti, H., Pitty, A., and Owen, M. (2011). Environmental effects on velvetleaf (Abutilon theophrasti) epicuticular wax deposition and herbicide absorption. Weed Sci. 59, 14-21. doi: 10.1614/WS-D-10-00061.1

Heap, I. (2016). International Survey of Herbicide Resistant Weeds. Available online at: http://www.weedscience.org

Jasieniuk, M., Brûlé-Babel, A. L., and Morrison, I. N. (1996). The evolution and genetics of herbicide resistance in weeds. Weed Sci. 44, 176-193.
Jimenez, F., Fernandez, P., Rosario, J., Gonzalez-Torralva, F., and De Prado, R. (2014). First Case of Glyphosate Resistance in the Dominican Republic. AGRO-554 in 248th ACS National Meeting and Exposition. San Francisco, CA: American Chemical Society.

Joshi, S. (1991). Interference effects of Cassia uniflora Mill on Parthenium hysterophorus L. Plant Soil. 132, 213-218. doi: 10.1007/BF00010402

Jussaume, R. A., and Ervin, D. (2016). Understanding weed resistance as a wicked problem to improve weed management decisions. Weed Sci. 64, 559-569. doi: 10.1614/WS-D-15-00131.1

Kaundun, S. S., Dale, R. P., Zelaya, I. A., Dinelli, G., Marotti, I., McIndoe, E., et al. (2011). A novel P106L mutation in EPSPS and an unknown mechanism(s) act additively to confer resistance to glyphosate in a South African Lolium rigidum population. J. Agric. Food Chem. 59, 3227-3233. doi: 10.1021/jf1 $04934 \mathrm{j}$

Klee, H., Horsch, R., and Rogers, S. (1987). Agrobacterium-mediated plant transformation and its further applications to plant biology. Annu. Rev. Plant Phys. 38, 467-486.

Komoba, D., Gennity, I., and Sandermann, H. (1992). Plant metabolism of herbicides with C-P bonds: glyphosate. Pestic. Biochem. Physiol. 43, 85-94.

Liu, C. M., McLean, P. A., Sookdeo, C. C., and Cannon, F. C. (1991). Degradation of the herbicide glyphosate by members of the family Rhizobiaceae. Appl. Environ. Microbiol. 57, 1799-1804.

Matzrafi, M., Seiwert, B., Reemtsma, T., and Rubin, B. (2016). Climate change increases the risk of herbicide-resistant weeds due to enhanced detoxification. Planta 244, 1217-1227. doi: 10.1007/s00425-016-2577-4

Michitte, P., De Prado, R., Espinoza, N., Ruiz-Santaella, J. P., and Gauvrit, C. (2007). Mechanisms of resistance to glyphosate in a ryegrass (Lolium multiflorum) biotype from Chile. Weed Sci. 55, 435-440. doi: 10.1614/WS-06-167.1

Monquero, P. A., Christoffoleti, P. J., Osuna, M. D., and De Prado, R. A. (2004). Absorção, translocação e metabolismo do glyphosate por plantas tolerantes e suscetíveis a este herbicida. Planta Daninha 22, 445-451. doi: 10.1590/S0100-83582004000300015

Nandula, V. K., Ray, J. D., Ribeiro, D. N., Pan, Z., and Reddy, K. N. (2013). Glyphosate resistance in tall waterhemp (Amaranthus tuberculatus) from Mississippi is due to both altered target-site and nontarget-site mechanisms. Weed Sci. 61, 374-383. doi: 10.1614/WS-D-12-00155.1

Navie, S. C., Panetta, F. D., McFadyen, R. E., and Adkins, S. W. (2004) Germinable soil seedbanks of central Queensland rangelands invaded by the exotic weed Parthenium hysterophorus L. Weed Biol. Manag. 4, 154-167. doi: 10.1111/j.1445-6664.2004.00132.x

Neve, P., Busi, R., Renton, M., and Vila-Aiub, M. M. (2014). Expanding the eco-evolutionary context of herbicide resistance research. Pest Manag. Sci. 70, 1385-1393. doi: 10.1002/ps.3757

Owen, M. D. K. (2016). Diverse approaches to herbicides-resistant weed management. Weed Sci. 64, 570-584. doi: 10.1614/WS-D-1500117.1

Pandey, D. K., Palni, L. M. S., and Joshi, S. C. (2003). Growth, reproduction, and photosynthesis of ragweed parthenium (Parthenium hysterophorus). Weed Sci. 51, 191-201. doi: 10.1614/0043-1745(2003)051[0191:GRAPOR]2. $0 . \mathrm{CO} ; 2$

Parker, A. (1989). "Biological control of Parthenium weed using two rust fungi," in Proceedings of the 7th International Symposium on Biological Control of Weeds, ed E. S. Delfosse, (Rome, March 1988. Rome/Melbourne; Ministero d' Agricoltura e delle Foreste/CSIRO), 27-36.

Pistón, F. (2013). Sarcosil RNA v1.2. RNA Isolation from Wheat Endosperm. Available online at: https://sites.google.com/site/fpistonprotocols/sarcosil (Accessed March 2016).

Powles, S. B., Lorraine-Colwill, D. F., Dellow, J. J., and Preston, C. (1998). Evolved resistance to glyphosate in rigid ryegrass (Lolium Rigidum) in Australia. Weed Sci. 46, 604-607.

Preston, C., and Wakelin, A. M. (2008). Resistance to glyphosate from altered herbicide translocation patterns. Pest Manag. Sci. 64, 372-376. doi: $10.1002 / p s .1489$

R Core Team (2015). R: A Language and Environment for Statistical Computing. Vienna: R Foundation for Statistical Computing. Available online at: https:// www.R-project.org/ 
Renton, M., Busi, R., Neve, P., Thornby, D., and Vila-Aiub, M. M. (2014). Herbicide resistance modelling: past, present and future. Pest Manag. Sci. 70, 1394-1404. doi: 10.1002/ps.3773

Ritz, C., Baty, F., Streibig, J. C., and Gerhard, D. (2015). Dose-response analysis using R. PLoS ONE 10:e0146021. doi: 10.1371/journal.pone.0146021

Rojano-Delgado, A. M., Cruz-Hipólito, H., De Prado, R., Luque-de Castro, M. D., and Rodríguez-Franco, A. (2012). Limited uptake, translocation and enhanced metabolic degradation contribute to glyphosate tolerance in Mucuna pruriens var. utilis plants. Phytochemistry 73, 34-41. doi: $10.1016 /$ j.phytochem.2011.09.007

Rojano-Delgado, A. M., Ruiz-Jiménez, J., De Castro, M. D. L., and De Prado, R. (2010). Determination of glyphosate and its metabolites in plant material by reversed-polarity $\mathrm{CE}$ with indirect absorptiometric detection. Electrophoresis 31, 1423-1430. doi: 10.1002/elps.200900583

Rosario, J., Fuentes, C., and De Prado, R. (2013). Resistencia de Parthenium hysterophorus L. al glifosato: un nuevo biotipo resistente a herbicida en Colombia. Rev. Agropecuaria Forest. 2, 15-18.

Salas, R. A., Dayan, F. E., Pan, Z., Watson, S. B., Dickson, J. W., Scott, R. C., et al. (2012). EPSPS gene amplification in glyphosate-resistant Italian ryegrass (Lolium perenne ssp. multiflorum) from Arkansas. Pest Manag. Sci. 68, 1223-1230. doi: 10.1002/ps.3342

Salas, R. A., Scott, R. C., Dayan, F. E., and Burgos, N. R. (2015). EPSPS gene amplification in glyphosate-resistant Italian ryegrass (Lolium perenne ssp. multiflorum) from Arkansas (USA). J. Agric. Food Chem. 63, 5885-5893. doi: 10.1021/acs.jafc.5b00018

Sammons, R. D., and Gaines, T. A. (2014). Glyphosate resistance: state of knowledge. Pest Manag. Sci. 70, 1367-1377. doi: 10.1002/ps.3743

Santos, J. I., Amaral, C. L., Alves, P. L., and Gasparino, E. C. (2016). Can light intensity influence the tolerance of Synedrellopsis grisebachii to glyphosate. Weed Biol. Manag. 16, 3-15. doi: 10.1111/wbm.12085

Saroha, M. K., Sridhar, P., and Malik, V. (1998). Glyphosate-tolerant crops: genes and enzymes. J. Plant Biochem. Biotech. 7, 65-72.

Seefeldt, S. S., Jensen, J. E., and Fuerst, E. P. (1995). Log-logistic analysis of herbicide dose-response relationships. Weed Technol. 9, 218-227.

Shaner, D. L., and Beckie, H. J. (2014). The future for weed control and technology. Pest Manag. Sci. 70, 1329-1339. doi: 10.1002/ps.3706

Shaner, D. L., Lindenmeyer, R. B., and Ostlie, M. H. (2012). What have the mechanisms of resistance to glyphosate taught us? Pest Manag. Sci. 68, 3-9. doi: $10.1002 /$ ps. 2261

Shaner, D. L., Nadler-Hassar, T., Henry, W. B., and Koger, C. H. (2005). A rapid in vivo shikimate accumulation assay with excised leaf discs. Weed Sci. 53, 769-774. doi: 10.1614/WS-05-009R.1

Shepherd, T., and Griffiths, D. W. (2006). The effects of stress on plant cuticular waxes. New Phytol. 171, 469-499. doi: 10.1111/j.1469-8137.2006.01826.x
Shingh, B. K., and Shaner, D. L. (1998). Rapid determination of glyphosate injury to plants and identification of glyphosate-resistant plants. Weed Technol. 12, 527-530.

Székács, A., and Darvas, B. (2012). "Forty years with glyphosate," in Herbicides Properties, Synthesis, and Control of Weeds, ed M. N. A. E Hasaneen, (Rijeka: In Tech), 247-284.

Vila-Aiub, M. M., Balbi, M. C., Distéfano, A. J., Fernández, L., Hopp, E., Yu, Q., et al. (2012). Glyphosate resistance in perennial Sorghum halepense (Johnsongrass), endowed by reduced glyphosate translocation and leaf uptake. Pest Manag. Sci. 68, 430-436. doi: 10.1002/ps. 2286

Wakelin, A. M., Lorraine-Colwill, D. F., and Preston, C. (2004). Glyphosate resistance in four different populations of Lolium rigidum is associated with reduced translocation of glyphosate to meristematic zones. Weed Res. 44, 453-459. doi: 10.1111/j.1365-3180.2004.00421.x

Wang, C. J., and Liu, Z. Q. (2007). Foliar uptake of pesticides. Present status and future challenge. Pest Biochem. Physiol. 87, 1-8. doi: 10.1016/j.pestbp.2006.04.004

Yu, Q., Cairns, A., and Powles, S. (2007). Glyphosate, paraquat and ACCase multiple herbicide resistance evolved in a Lolium rigidum biotype. Planta 225, 499-513. doi: 10.1007/s00425-006-0364-3

Yu, Q., Han, H., Vila-Aiub, M. M., and Powles, S. B. (2010). AHAS herbicide resistance endowing mutations: effect on AHAS functionality and plant growth. J. Exp. Bot. 61, 3925-3934. doi: 10.1093/jxb/erq205

Yu, Q., Jalaludin, A., Han, H., Chen, M., Sammons, R. D., and Powles, S. B. (2015). Evolution of a double amino acid substitution in the 5enolpyruvylshikimate-3-phosphate synthase in Eleusine indica conferring highlevel glyphosate resistance. Plant Physiol. 167, 1440-1447. doi: 10.1104/pp.15. 00146

Yuan, J. S., Tranel, P. J., and Steward, C. N. Jr. (2006). Non-target-site herbicide resistance: a family business. TRENDS Plant Sci. 12, 6-13. doi: $10.1016 /$ j.tplants.2006.11.001

Conflict of Interest Statement: The authors declare that the research was conducted in the absence of any commercial or financial relationships that could be construed as a potential conflict of interest.

Copyright (c) 2016 Bracamonte, Fernández-Moreno, Barro and De Prado. This is an open-access article distributed under the terms of the Creative Commons Attribution License (CC BY). The use, distribution or reproduction in other forums is permitted, provided the original author(s) or licensor are credited and that the original publication in this journal is cited, in accordance with accepted academic practice. No use, distribution or reproduction is permitted which does not comply with these terms. 